\title{
Microwave Processing of Materials
}

\author{
by
}

Samuel William Kingman

Dissertation presented for the Degree

\author{
of \\ DOCTOR OF ENGINEERING \\ (Chemical Engineering)

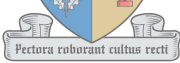 \\ UNIVERSITEIT \\ iYUNIVESITH1 \\ STELLENBOSCH \\ in the Faculty of Engineering \\ at Stellenbosch University \\ 1918.2018 \\ Supervisor \\ Professor Steven Bradshaw
}

March 2018 


\section{Declaration}

By submitting this dissertation electronically, I declare that the entirety of the work contained therein is my own, original work, that I am the sole author thereof (save to the extent explicitly otherwise stated), that reproduction and publication thereof by Stellenbosch University will not infringe any third party rights and that I have not previously in its entirety or in part submitted it for obtaining any qualification.

This dissertation contains eighty five original papers published in peer-reviewed journals. The development and writing of the papers (published and unpublished) was the principal responsibility of myself and, for each of the cases where this is not the case, a declaration is included in the dissertation indicating the nature and extent of the contributions of co-authors.

Date March 2018

Copyright @ 2018 Stellenbosch University

All rights reserved 


\section{Abstract}

The world is under increasing pressure to develop new, more energy-efficient technologies that enable the production of less waste and are more sustainable. Material processing through microwave energy has received academic attention in the past few years for potentially delivering environmental benefits for a number of different applications including, food, fine and bulk chemicals, oil and gas, minerals and metals extraction. Despite the potential to deliver a step change in overall process efficiency across a diverse range of sectors, the true economic value of microwave technology has generally not being realised.

My work in microwave processing commenced in 1996 with my PhD at the University of Birmingham where I began investigations into the interaction of microwave energy with metal ores in order to reduce grinding energy and improve liberation of valuable minerals. Even at this early stage it became apparent that despite a strong body of literature reporting laboratory studies there was very little knowledge supporting the scale up of microwave technologies for application in industrial processing. Further investigation into other potential application areas such as chemistry, materials processing, drying and food processing demonstrated that similar barriers existed with few if any commercial implementations of basic research realised.

I have sought to identify the reasons why scale up of microwave heating is a challenge, to identify solutions to some of the major technical barriers and to develop generic methodologies which can be applied to different material systems across multiple industries. Such barriers relate to a lack of understanding of the interaction of microwaves with materials at a molecular level, lack of a multi-disciplinary approach to scale up, poorly understood value propositions for the use of microwave technology, and a lack of a trained workforce to support technology implementation in industry. Ultimately, it is also true that due to the high capital cost of microwave technology the ability to identify process benefits that can only be delivered through microwave heating alone, rather through cheaper conventional heating technologies is critical for successful commercialisation.

Addressing these barriers has led me to develop, in collaboration with colleagues from across the globe, methodologies for the scale up of microwave technology. Identification of the interaction mechanism with the material to be processed, be it bulk 
or selective heating exemplified through the use of dielectric property measurements at both extremes of temperature and pressure has been reported as has modelling of the impact of rapid heating on material matrices. Studies which have proven the mechanism by which microwaves deliver value through multiple interactions have been reported for numerous different material classes and systems often at the highest power inputs ever reported. Scale up of systems through collaboration with experts in microwave design, materials handling and chemical reaction engineering have been reported for different applications, each providing a basis for the scale up of the technology. In several cases including rock fracture and sorting, oil and drilling waste processing and vermiculite exfoliation this has led to the development of unique microwave technologies. In the case of mineral sorting and fracture this work has directly underpinned the highest throughput microwave processing systems ever built. 


\section{Opsomming}

Die wêreld is onder toenemende druk om nuwe, energiedoeltreffender tegnologieë te ontwikkel wat sal help om afvalproduksie te verminder en wat meer volhoubaar is. Materiaalverwerking deur mikrogolfenergie het in die afgelope paar jaar aandag op akademiese gebied geniet vanweë die moontlike omgewingsvoordele wat dit vir verskillende toepassings, onder meer die onttrekking van voedsel, fyn en growwe chemikalieë, olie en gas, minerale en metale, inhou. Afgesien van die potensiaal om 'n faseverandering in oorhoofse prosesdoeltreffendheid oor 'n uiteenlopende verskeidenheid sektore te kan lewer, word die werklike ekonomiese waarde van mikrogolftegnologie oor die algemeen nog nie besef nie.

My werk in mikrogolfverwerking het tydens my PhD-studie in 1995 aan die Universiteit van Birmingham begin met ondersoeke na die interaksie tussen mikrogolfenergie en mataalertse ten einde slypenergie te verminder en die loslating van kosbare minerale te verbeter. Selfs in daardie vroeë stadium was dit duidelik dat ondanks 'n uitgebreide korpus literatuur wat oor laboratoriumondersoeke berig, daar baie min kennis bestaan ter ondersteuning van die opskaling van mikrogolftegnologieë vir toepassing in bedryfsverwerking. Verdere ondersoeke na ander potensiële toepassingsareas soos chemie, materiaalverwerking, droging en voedselverwerking, het bevind dat daar soortgelyke struikelblokke is en dat min, indien enige, kommersiële toepassings vir basiese bewese navorsing gerealiseer het.

Ek het ondersoek ingestel na die redes waarom die opskaling van mikrogolfverhitting uitdagings stel ten einde oplossings te vind vir van die belangrikste tegniese struikelblokke, asook om generiese metodologieë te ontwikkel wat op verskillende materiaalsisteme oor verskeie industrieë heen toegepas kan word. Hierdie struikelblokke het te make met 'n gebrek aan insig rakende die interaksie tussen mikrogolwe en materiale op 'n molekulêre vlak, die gebrek aan 'n multidissiplinêre benadering tot opskaling, onvoldoende insig in waardevoorstelle vir die gebruik van mikrogolftegnologie, en 'n gebrek aan 'n opgeleide werksmag om tegnologieimplementering in die bedryf te ondersteun. Uiteindelik moet daar in gedagte gehou word dat vanweë die hoë kapitaalkoste van mikrogolftegnologie, die vermoë om prosesvoordele te identifiseer wat slegs deur mikrogolfverhitting gelewer kan word in plaas van deur goedkoper, konvensionele verhittingstegnologieë - krities vir suksesvolle kommersialisering is. 
Tydens die aanpak van hierdie struikelblokke het ek metodologieë vir die opskaling van mikrogolftegnologie in samewerking met kollegas oor die hele wêreld ontwikkel. Identifisering van die interaksiemeganisme met die materiaal wat verwerk moet word, hetsy massa- of selektiewe verhitting, toegelig deur die gebruik van diëlektriese eienskapmetings teen sowel temperatuur- as drukuiterstes, is aangemeld, asook die modellering van die impak van snelverhitting op materiaalmatrikse. Studies is aangemeld ter stawing van die meganisme waarvolgens mikrogolwe deur veelvoudige interaksies vir 'n verskeidenheid materiaalklasse en -sisteme waarde lewer, dikwels teen die hoogste kraginsette wat tot dusver gerapporteer is. Stelselopskaling deur medewerking met kundiges in mikrogolfontwerp, materiaalhantering en chemiesereaksie-ingenieurswese is vir verskillende toepassings aangemeld, wat elkeen ' $n$ basis vir die opskaling van die tegnologie bied. In verskeie gevalle, waaronder rotsbreking en -sortering, olie- en boorafval-verwerking en vermikulietafskilfering, het dit tot die ontwikkeling van unieke mikrogolftegnologieë gelei. In die geval van mineraalsortering en -breking het hierdie werk die direkte motivering verskaf vir die bou van mikrogolfverwerkingstelsels met die hoogste verwerkingskapasiteit tot op hede. 


\section{Acknowledgements}

One of my early conclusions as I worked to scale up industrial microwave processing systems was the need for multi-disciplinary collaboration. Therefore, in almost all of the work presented here I wish to acknowledge a number of extensive and highly valuable collaborations without which the work would not have been completed. I appreciate this opportunity to thank a significant number of colleagues, collaborators, funders and supporters who have, in their own way, contributed to the outcomes presented.

- Professor Neil Rowson of the University of Birmingham, who gave me the opportunity to start working in microwave processing

- Dr Chris Cross previously of Rio Tinto who noticed the work on microwave processing of minerals at a very early stage and had faith to support it when others said that it would never work

- The Engineering and Physical Sciences Research Council who supported so much of the early work.

- Key University of Nottingham collaborators who enabled a plethora of new applications of microwave technology through their own expertise; Dr John Robinson, Dr George Dimitrakis, Professor Derek Irvine and Prof Ed Lester

- Professor Howard Reader from Stellenbosch University, from whom I learnt some of the key fundamentals of microwave heating

- Industrial project funders without whom much of this work would have been delivered, BP, Shell, Teledyne-e2v, Rio Tinto, BHP, Anglo American, AMIRA International, NOV Brandt and others

- Colleagues and collaborators from organisations with whom I have worked including University of Queensland, Imperial College London, University of Manchester, Rio Tinto Technology Development, NOV Brandt, Teledyne e2v, BP and British Gas

- Colleagues and collaborators from the High Power RF Faraday Partnership from where for the first time I was able to identify supply chain partners who were able to make my technology vison an industrial reality

- All of my postdoctoral researchers and students with special mention to Drs Chris Dodds, Aled Jones, Juliano Katrib, Andrew Batchelor and Adam Buttress 
I would also like to thank Stellenbosch University for the opportunity to write this thesis. I also wish to thank my promoter Professor Steven Bradshaw, not just for his support and encouragement in the submission of this thesis, but for the collaboration and discussions which underpinned much of the early work it contains.

This thesis is dedicated to my wife Ann, in recognition of her unfailing support and her patience for coping with numerous lonely weeks and weekends over multiple years as I travelled the world looking for funding to support the development of microwave processing systems. 


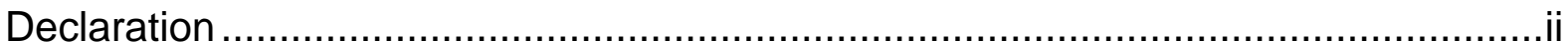

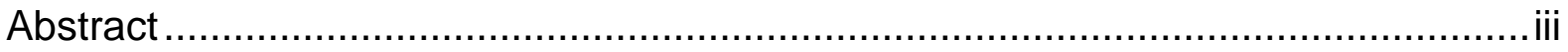

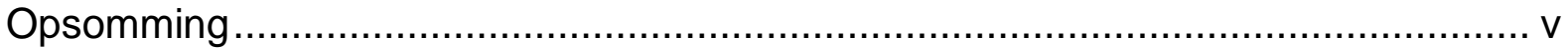

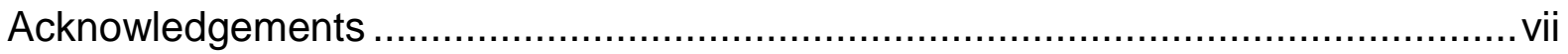

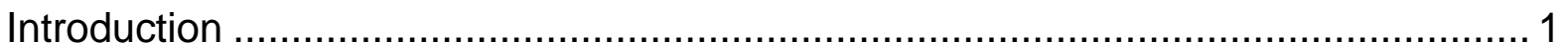

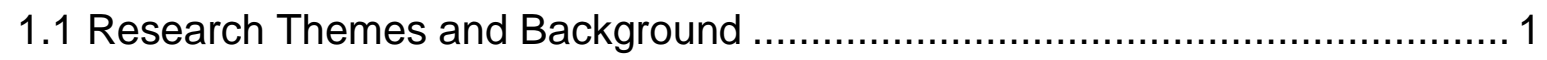

Barrier 1: Need for a Stronger Fundamental Science Requirement ...................... 3

Barrier 2: Lack of a Multi-Disciplinary Approach .............................................. 3

Barrier 3: Poorly Defined and Understood Value Proposition ................................ 4

Barrier 4: Lack of Demonstration at the Appropriate Scale ................................... 4

Barrier 5: Requirement for a Trained Workforce to Support ................................. 5

1.2 Impact of Research in the Engineering Industry ....................................... 5

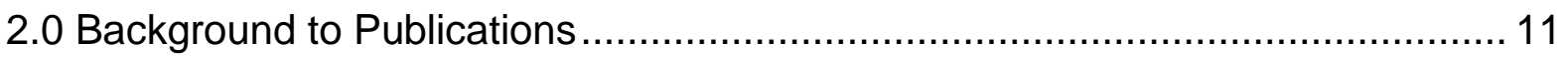

2.1 Microwave Applications in Mining and Minerals Processing......................... 11

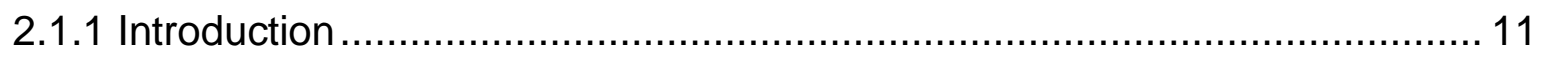

2.1.2 Towards Economic Feasibility of Microwave Comminution ........................ 12

2.1.3 Hydrometallurgical Applications of Microwave Heating …........................ 14

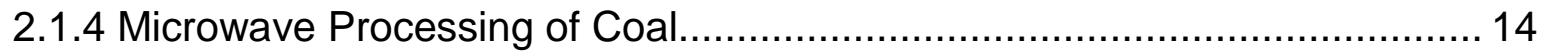

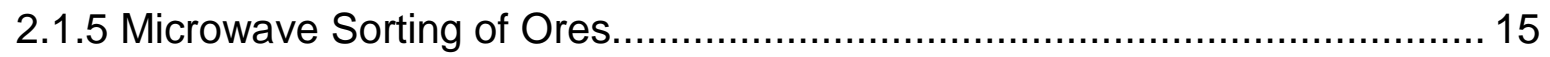

2.1.6 Microwave Expansion of Vermiculite ….............................................. 17

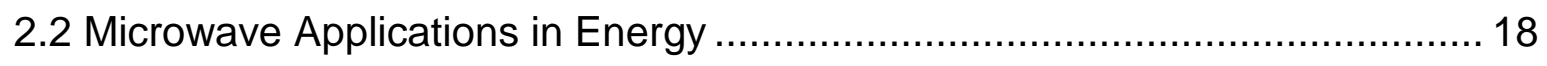

2.2.1 Microwave Processing of Oil Contaminated Drill Cuttings ........................ 18

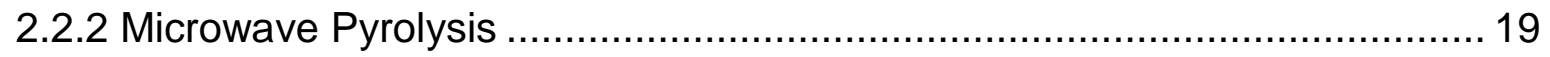

2.3 Other Applications of Microwave Heating Technology.................................. 20

3.0 Summary of Most Significant Research Contributions ................................... 22

Appendix 1: Lists of Publications included in this Submission and Referred to in

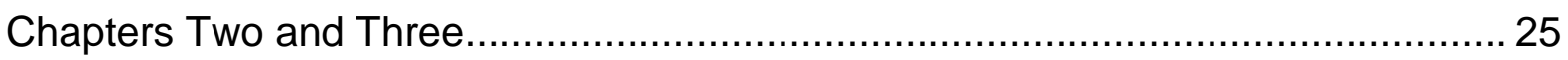

Appendix 2: List of Journal Papers not included in this Submission......................... 35

Appendix 3: Patents on which I am an Inventor ................................................. 38

Appendix 4: Postdoctoral Researchers and PhD Students Supervised .................. 46

Postdoctoral and Other Researchers Employed............................................ 46

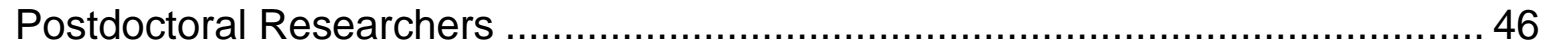

Supervisor of Graduated Doctoral Students ................................................. 46 
Appendix 5: Prizes, Awards and Distinctions Related to Research in this Thesis .... 48

Appendix 6: Research Sponsors who have supported Research Activities 


\section{Introduction}

\subsection{Research Themes and Background}

I have been involved in the microwave processing of materials since 1996 when I started my PhD under the supervision of Professor Neil Rowson at the University of Birmingham, UK. Throughout this time I have been fascinated by the interaction of electromagnetic waves with materials, the impact of ultra-rapid heating on the physical and chemical properties of matter, the ability to heat selectively and volumetrically and the impact that these phenomena can have on the economics of a process, be that chemical, metallurgical, or biological. Of course, the study of microwave interactions with materials is not new and there are literally thousands of reports of the interaction of electromagnetic waves with materials across almost all subject areas studied by researchers. Perhaps in a different way to many of the other researchers, my interests lie not just in the interaction of electromagnetic energy with the materials within a laboratory environment, but crucially how to translate these benefits to an industrial setting; a setting where the true benefits of volumetric and selective heating can be realised in terms of energy saving, increased product quality, reduced plant footprint and ultimately cost reduction can be realised. I started my academic career as a lecturer at Nottingham University in September 2000. From a literature search on Scopus $^{1}$ it is interesting to note that there were 421 papers recorded that year which could be found through using the search terms "Microwave and Heating". Figure 1 below shows a plot of the total number of publications produced each year since 2007 for the same search terms.

\footnotetext{
${ }^{1}$ www.scopus.com
} 


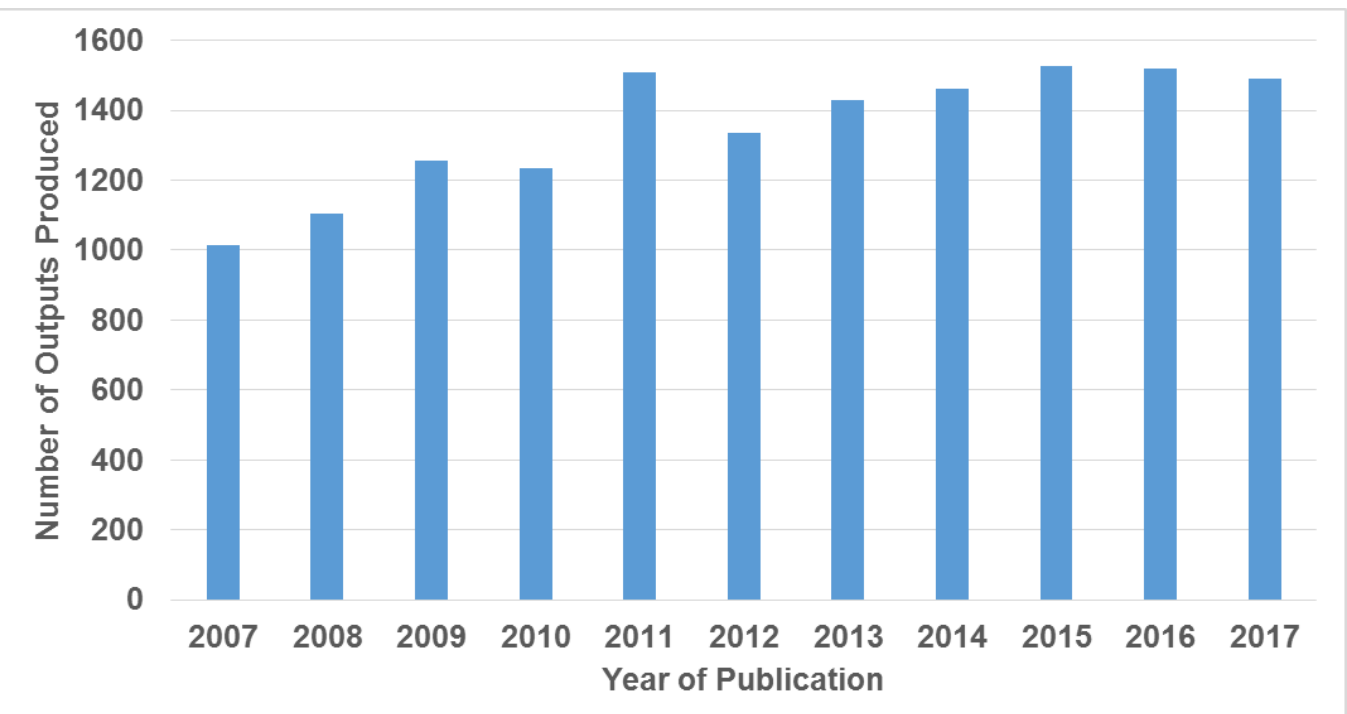

Figure 1. Total number of publications produced each year from 2008 - 2017 from a Scopus Search for "Microwaves and Heating"

From just 421 outputs in 2000, the number of publications reporting the results of work in microwave heating has grown significantly, with over 1500 papers a year now being produced. A detailed study of this literature shows almost exclusively laboratory studies, a few grams of material often being heated in generic multimode cavities, indeed often still based around the somewhat ubiquitous kitchen microwave oven. Whilst this is quite remarkable growth in activity, very little of the work is actually translated to industrial scale and much unfortunately remains an academic curiosity despite most having admirable vision in terms of reducing energy consumption, producing new products or processes, or improving the efficiency of existing processes.

I have spent a significant proportion of my research career attempting to understand the barriers to commercialisation of microwave processing. Trying to understand why thousands of publications are produced by researchers all over the globe but yet so few processes ever reach commercial scale. The themes identified here will be referred to throughout this thesis as I detail the work done by myself and my collaborators.

There are very few if any published accounts of failure to scale up microwave technology (for obvious reasons!). Therefore, my views of why microwave technology has traditionally been hard to scale up are founded upon discussions with those who have tried and failed, microwave equipment manufacturers from around the world, process engineers involved in unsuccessful and successful projects and from my own 
experiences working with industry. As such I have identified the following barriers to commercialisation of microwave processing technology.

\section{Barrier 1: Need for a Stronger Fundamental Science Requirement}

The vast majority of studies into microwave heating of a particular material follow a similar pattern. The material in question is characterised to a greater or lesser extent, heated at a range of powers and residence times and the impact of the heating is then determined through some sort of characterisation of the product. Few studies consider the design of the microwave cavity, the electric field structure supported and how this couples with the material in question. Few studies consider the efficiency of coupling, i.e. how much energy is actually adsorbed by the material under treatment. Few consider how the dielectric properties of the materials to be processed change with temperature, frequency or the local environment (with some notable exceptions). In short, there is in many cases, little understanding of the interaction of microwave energy with the material in question. All of these data are crucial when scale up of a process is considered as will be shown in Chapter 2, Background to the Publications. Failure to determine these factors is the first barrier to scale up.

\section{Barrier 2: Lack of a Multi-Disciplinary Approach}

Work reported in this thesis shows for many different materials the steps required for successful scale up. A key facet of this methodology is the need for multi-disciplinarity. A core requirement is a robust understanding of microwave engineering, dielectric properties of the material to be processed, and microwave applicator design for example. However, how such technologies interact with chemical engineering, particularly heat and mass transfer and for liquid systems reactor design; materials handling technology for solids systems is also crucial with movement of a controlled flow of material into and out of the applicator far more important in many cases than the design of the microwave cavity itself. In many of the published papers in the literature there is a lack of a multi-disciplinary approach, to the point where this is an exception rather than a rule. This lack of a multi-disciplinary approach leads to compromise in terms of understanding which ultimately is the second barrier to scale up of industrial microwave technology. 
Barrier 3: Poorly Defined and Understood Value Proposition

It is true that several of the publications reporting the interaction of microwave energy with materials are using microwaves simply as a heat source and there is no interest in the interaction of the electromagnetic waves with the structure of the materials. However, in many, the authors report the proposed technology as a potential solution to a key industrial problem. Primarily, these relate to energy saving or reduction, development of new materials with enhanced properties, faster more efficient reactions, overcoming mass and heat transfer limitations in conventional processing, reduced plant footprint or some other benefit realised through selective or volumetric heating. Whilst there is no doubt that many studies report the potential for substantial technical benefits, very few consider the value proposition for that process at any level, even though a simple energy balance. This, however, is not surprising as even a simple energy balance is difficult to achieve without an optimised applicator and in many cases the energy added to the process will be orders of magnitude higher in a generic "off the shelf" applicator than one that has been designed specifically for the application. Given Barrier 2 above, the lack of multi-disciplinarity shown in previous work, it is unsurprising that few papers report the use of optimised microwave applicators leading to uneconomic processes being reported. It is likely, therefore, that the reason for the lack of scale up in many processes reported relates to the fact that the use of microwaves is simply uneconomic or that the economics of the process are unknown. For industry, this is a major barrier as industry will not invest in research and development where the economic case is poorly defined. In the case of microwaves this is particularly relevant as the cost of microwave energy is significantly higher than conventional heating technologies such as gas.

\section{Barrier 4: Lack of Demonstration at the Appropriate Scale}

Certainly it was true in the earlier days of microwave processing research that the majority of studies were reported in domestic microwave ovens modified in some way for the purposes of the experiment. Over the past 10 years, more specialised microwave systems have been built for microwave heated chemical reactions in particular which allow measurement of power (forward and reflected), bulk temperature and allow in some cases the positioning of the sample to be heated in the zone of highest field intensity. Despite this, however, the majority of work reported outside of chemical reactions still uses generic multimode or occasionally single mode cavities. Use of such equipment does not support the required understanding to move 
towards large scale technology demonstration and can only really be used to determine if a material heats to a greater or lesser extent. Again, this is not a surprise because a domestic microwave oven can be easily purchased for US\$50 from many electrical outlets whilst even modest power levels produced by specialist microwave equipment may cost $>$ US $\$ 5000$, out of the reach of many researchers. If large scale processing with microwave is to be considered then the costs of the process system can be exorbitant, several of the systems reported in the papers in this thesis had a capital cost for the microwave system alone of over US\$750,000. Demonstration of the technology at different scales is, therefore, hard to achieve with very few facilities available around the world to do so. This in many cases has led to scale up disasters where small lab scale experiments have been scaled up to either pilot or industrial scale with no intermediate steps. Unfortunately, in most cases this leads to failure and a bad name being developed for microwave technology. Lack of availability of equipment for demonstration of technology at scale is the fourth barrier to scale up of microwave technology.

\section{Barrier 5: Requirement for a Trained Workforce to Support}

Without the required skill sets a process will never move out from the laboratory to the factory floor. For microwave processes which are often technically complex there are a myriad of skills required to underpin this journey; microwave and process engineering, materials science and process design and control for example. As the scale up journey continues the skill sets required will change with the need to raise investment, protect and secure IP, develop and maintain value propositions becoming crucial. Further skills are then required to develop a supply chain that has all of the correct partners able and willing to work together in a commercial framework. Process skills are then required for the operators, able to understand a new process and make it deliver the outcomes required from the value proposition in a safe and consistent manner. For new technologies pulling together all of these different skills is highly challenging and therefore, a fifth barrier to scale up of microwave technology is the requirement of a trained workforce to support. Of course this barrier relates to all technology not just microwave heating.

\subsection{Impact of Research in the Engineering Industry}

The previous section of this thesis describes in some detail the barriers to the scale up of microwave technology for industrial processing. Throughout my career I have 
developed solutions to these barriers which have enabled step change microwave processes to be developed to the point of commercialisation.

These processes are as follows:

1. Microwave induced fracture of ore to reduce energy consumption in comminution;

2. Microwave-infra-red sorting of copper ores to enhance throughput of mineral processing plants;

3. Microwave processing of oil and gas wastes to reduce the environment impact of off-shore drilling;

4. Microwave expansion of vermiculite mineral.

As previously identified in this thesis, one of the major barriers to scale up is lack of appropriate partnerships between academic and industry. This is true not just in terms of partnership with end users but also and probably more importantly with the supply chain. In 2003 it became clear that it would not be possible to transfer my developing technology from the laboratory to industry without a credible supply chain partner for production of microwave equipment and hardware. Many of the world's OEMs in this area are small companies with turnovers less than US $\$ 10 \mathrm{M}$, with negligible research budgets and a product portfolio which has not seen significant development over many years. Typically, these organisations are supplying hardware to local, well established applications of microwave technology in defrosting, bacon cooking, rubber curing, starch drying and expansion etc. Given the scale of some of the applications being worked on at the time, it is was vital that I was able to find a partner who was able to invest in new products, was able to be commercially attractive to the big blue chip multi-national organisations and crucially able to supply equipment at the appropriate cost, and with global technical support. It should also be noted that for the mining applications even pilot demonstration of the technology required the use of microwave power at unprecedented scales. Such a company was e2v technologies (now Teledyne-e2v) based in Chelmsford, Essex. The company began in the early 1940s as part of the Marconi group manufacturing magnetrons for defence radar systems and is now one of the largest producers of high power microwave tubes in the world. In 2005, I formed a strategic collaboration with e2v which still exists today and which 
crucially underpins all scale-up activities though providing a route to market for IP developed at the University of Nottingham

In Chapter 2 of this thesis I will discuss the research which relates to the 4 applications above. These applications are all very different, however, development of a generic scale up route for microwave technology underpins them all. A significant contribution to this work has been the development, jointly with e2v and Dr Chris Dodds at Nottingham, of generic methodologies for the scale up of microwave processes and these are reproduced in Figure $2 \mathrm{a}, 2 \mathrm{~b}$ and $2 \mathrm{c}$.

These flowsheets demonstrate the generic steps required to scale a microwave process and help address many of the barriers presented in the previous section of these thesis. Of course they massively simplify the challenges involved, both technologically and commercially, but hopefully provide a useful framework for the reader. It will be noted from Figure $2 c$ that often an exploitation partner is required, and this is particularly true where the scale of the process engineering challenges of the project are greater than the those of the microwave part of the process. In this case other third party engineering companies need to be identified and this has been the case in each of the projects listed above.

The value to $\mathrm{e} 2 \mathrm{v}$ of collaboration to me and my group was the subject of an impact case study submitted to the Higher Education Funding Council of England (HEFCE) Research Excellence Framework in $2014^{2}$. Here it was evidenced that since 2008, e2v had seen a multi-million pound increase in new business as a result of my research. The company had invested over $£ 8 \mathrm{M}$ in development of its own industrial microwave business and had grown as a direct result of the opportunities offered through their collaboration with the University of Nottingham from 3 to 50 people. In April 2012, e2v received a $£ 6.3 \mathrm{M}$ award from the UK Government Department of Business, Innovation and Skills (as was). This directly related to the research, development, manufacturing and marketing activities around the industrial microwave processing business, with the expectation that it will create approximately 200 jobs at e2v and close collaborators.

\footnotetext{
${ }^{2}$ www.ref2014.ac.uk (although this case study was redacted for confidentiality reasons)
} 


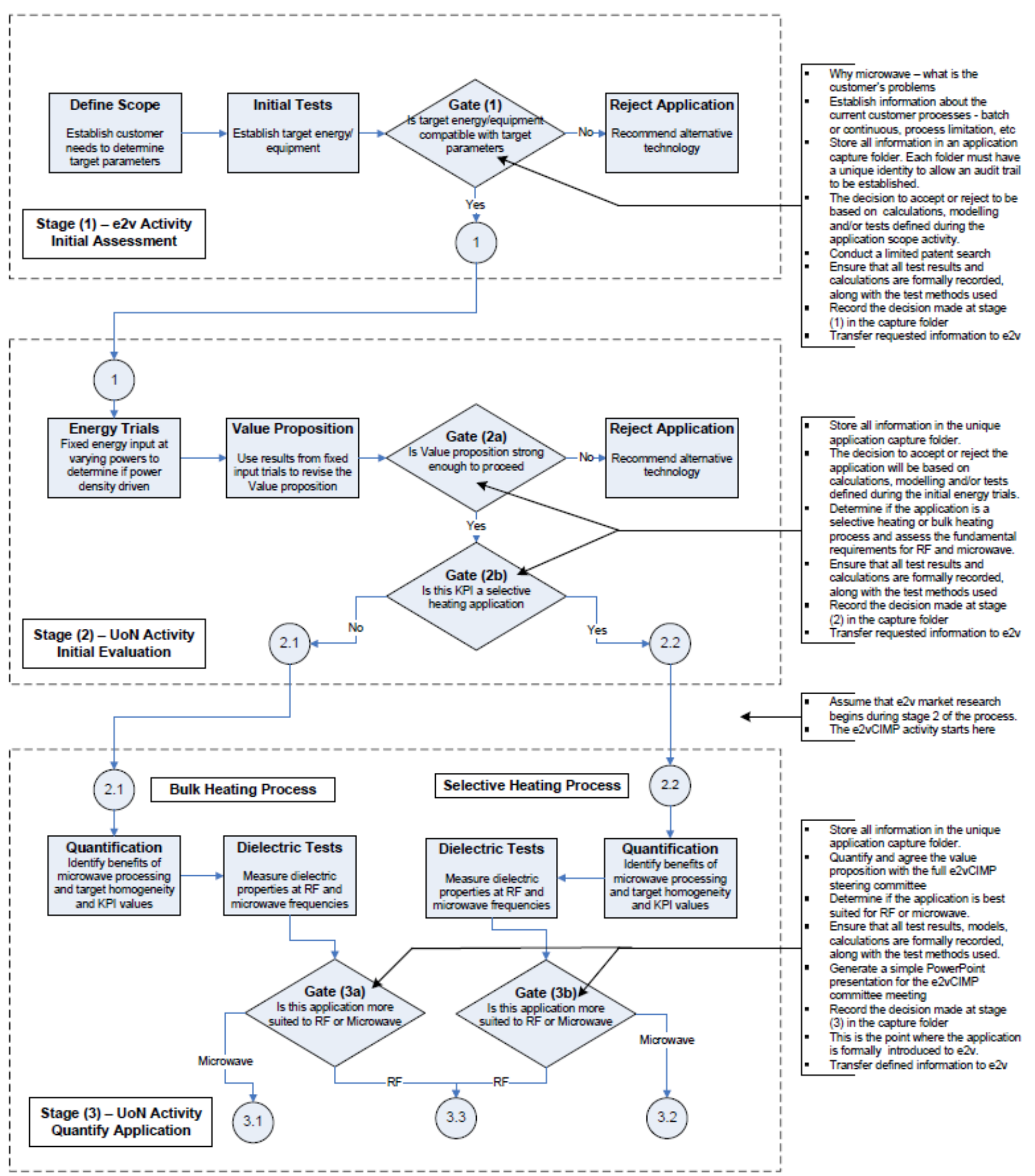

Figure 2a: Stage 1 of MW Application Development Process 


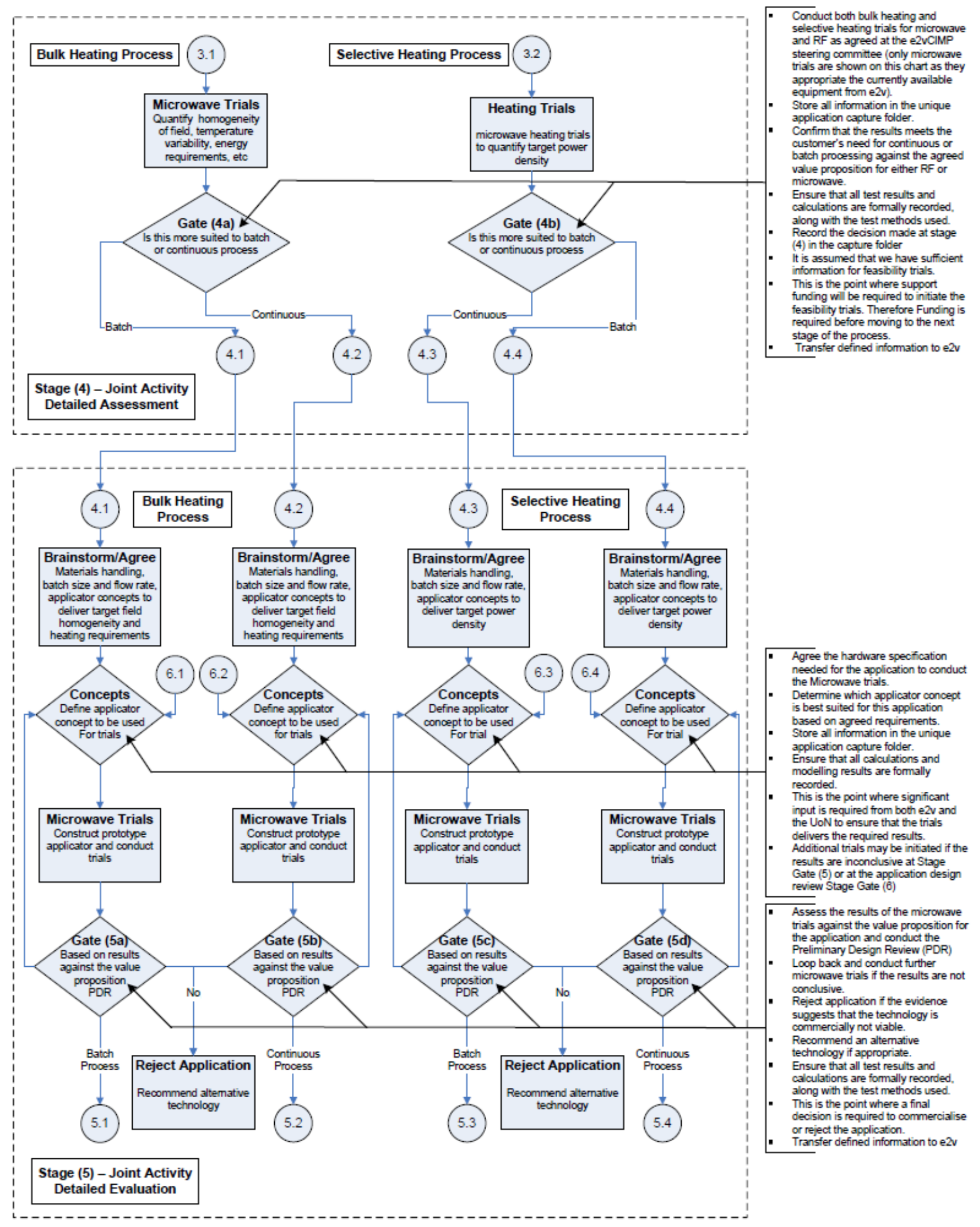

Figure 2b: Stage 2 of Application Development Process 


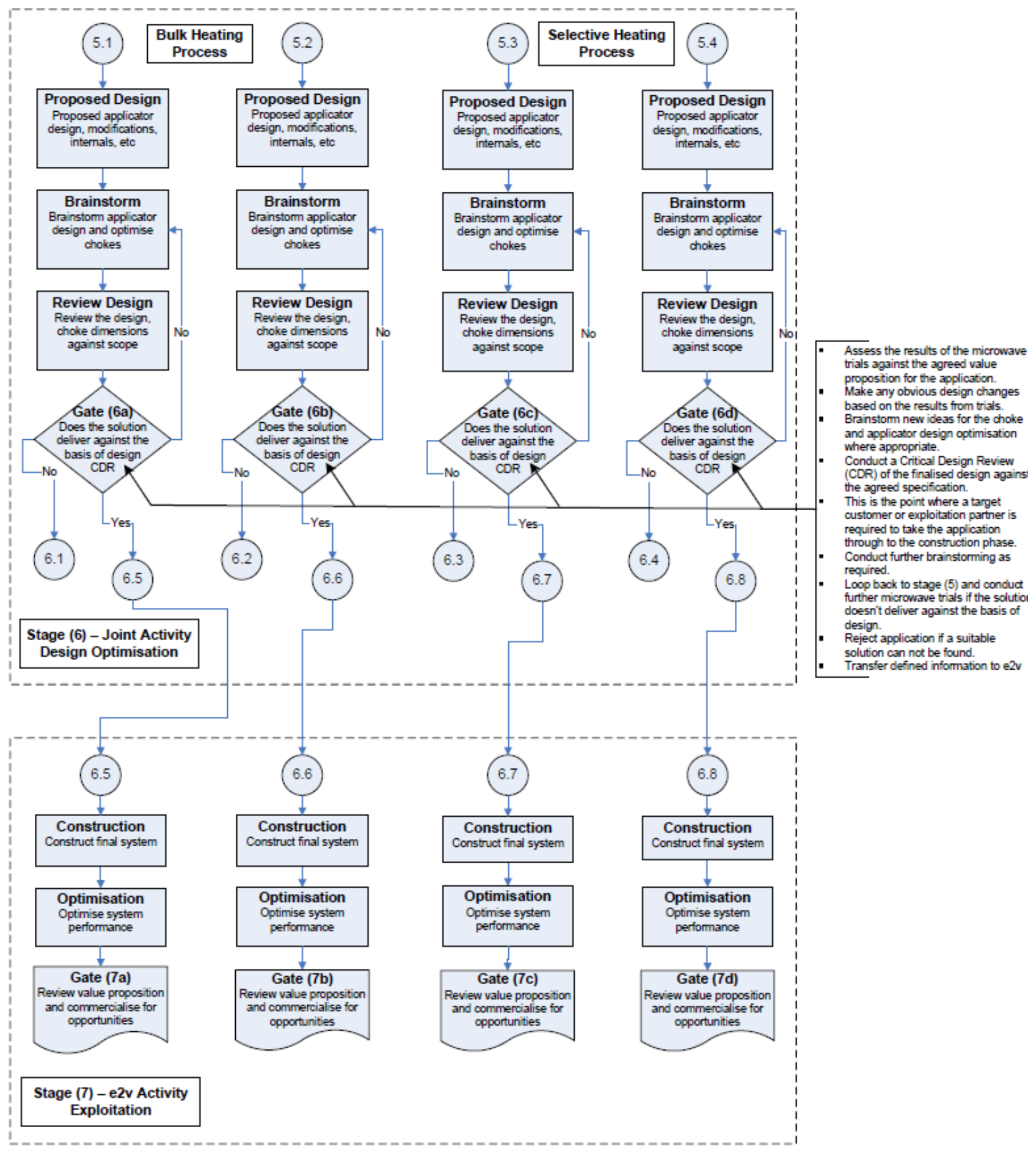

Figure 2c: Stage 3 of Application Development Process 


\subsection{Background to Publications}

\subsection{Microwave Applications in Mining and Minerals Processing}

\subsubsection{Introduction}

My first published paper was a review of the early research in microwave treatment of minerals [1]. This work concluded that although the amount of activity in the field was relatively limited, that which was published did show promise for the mineral industry in terms of reducing energy consumption. However, this work also showed that all of the studies to this point were exploratory in nature and performed at lab scale. Finally, recommendations were made which suggested that in order to develop microwave processing of minerals to a commercial scale several key pieces of research were required:

1. Minimisation of energy input into the ore samples

2. Frequency optimisation for maximum heating efficiency

3. Data concerning the effects of sample temperature on dielectric properties

4. Scale up to tonne/hr systems

This review was produced in 1998 and it is interesting to note that in a further review in 2006 [17] there was double the number of cited references showing a growing body of work, however the conclusions remained broadly the same in that the major challenge for industrial implementation of microwaves in minerals processing was the minimisation of energy input to the samples. It was also clear from both reviews that microwave enhanced comminution was the greatest area of activity and possibly the most important in terms of potential industrial impact.

Of course it is important to demonstrate the impact of microwave treatment on the comminution behaviour of ores and a number of publications were produced which demonstrated this $[2,3,4,82,83,84]$. It was clear from this work that texture and mineralogy were controlling factors in the degree of damage induced in the ore and, therefore, energy required to damage the ore. Ores that exhibited a coarse and consistent mineralogy containing a good heater in a transparent matrix were generally shown to give the greatest degree of fracture as determined by relative Bond work index. 


\subsubsection{Towards Economic Feasibility of Microwave Comminution}

It was clear from the early reviews that the energy input into the sample would drive the techno-economic assessment of microwave assisted comminution. The early work published showed microwave energy inputs of significantly greater than $10 \mathrm{kWh} / \mathrm{t}$, values which were actually higher than the values of energy they potentially saved. Modelling work that I performed with colleagues Dr Dave Whittles and Dr Dave Reddish (deceased) was to provide the breakthrough for all of the work to come and ultimate pave the way for scale of microwave assisted comminution for the first time [5]. Through simulation it was shown if that the power density (energy per unit volume in the heated phase) was increased but the residence time decreased then heat transfer into the bulk would be minimised leading to significant localised stress across and around the grain boundaries. This work showed that residence times in the microwave field as low as 0.05 seconds could give extensive fracture (shear planes at least) if power densities of $1 \times 10^{11} \mathrm{~W} / \mathrm{m}^{3}$ could be achieved. This result was particularly significant as it was shown for the first time that very short residence times could give rise to energy inputs of less than $1 \mathrm{kWh} / \mathrm{t}$, a tenth of what was demonstrated experimentally at the time.

Further work with my first PhD student Antonio Cumbane and Professor Steven Bradshaw at Stellenbosch University validated this modelling and showed that significant economic value in terms of grindability and liberation enhancements could be achieved at microwave energy inputs of less than $1 \mathrm{kWh} / \mathrm{t}$ as predicted by the models [7 8]. Further modelling work carried out with my PhD student Aled Jones was then used to determine the impacts of different ore textures and to identify that pulsed as opposed to continuous wave microwave energy delivery would deliver the best outcomes in terms of thermal stress generation at grain boundaries $[13,19]$.

With the work now beginning to catch the attention of industry, the first technoeconomic analyses were published through collaboration with colleagues both from Nottingham and from Stellenbosch University [14, 18]. It was around this time in 2007 , that serious industrial investment was realised to develop the concept of microwave 
assisted comminution. AMIRA International supported 2 projects, P879 and P879a 3 . These were a four year multi-partner, multi-disciplinary research programmes to treat different ores at pilot scale (20-100 tph) at economical microwave energy inputs and provide the scientific and engineering basis for industrial scale up. The use of pulsed microwave technology was shown to offer significant potential benefits compared to continuous wave equipment, including much reduced energy consumption and increased operating flexibility [27, 29].

Almost 20 years after the first review paper was published, in 2017, 2 papers reported for the first time a methodology, process and results which demonstrated the microwave treatment of ores at economic energy inputs continuously and at a throughput of $>150 \mathrm{t} / \mathrm{hr}$ [33. 34]. These papers, the result of collaborations led by myself with colleagues from Jenike and Johansson in the USA and JKTech in Australia and funded by Rio Tinto Technology and Innovation reported the design, construction and commissioning of a scaleable (from 150-3000 t/hr) plant (the highest throughput microwave processing plant ever built) and shown in Figure 3.

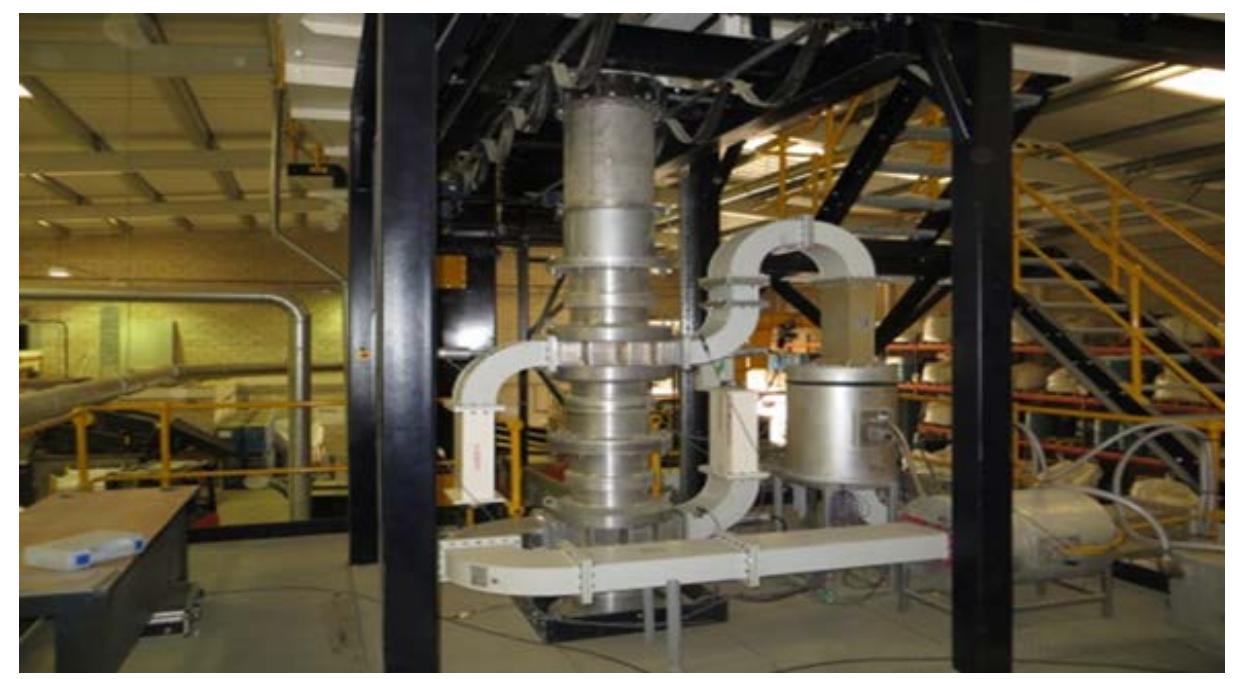

Figure 3. Microwave Applicator Showing 2 Microwave Feeds for the Treatment of

Ore at $150 \mathrm{t} / \mathrm{hr}$

The work also showed that the damage induced in the samples after treatment could lead to upto $24 \%$ reductions in total energy requirement with a subsequent $30 \%$ increase in mass throughput for a typical copper grinding circuit and at a microwave 694\&Source_ID=1 
energy input of less than $0.7 \mathrm{kWh} / \mathrm{t}$. Subsequent work by my PhD student Alex Ure showed that such benefits could be realised at a microwave energy input of $0.3 \mathrm{kWh} / \mathrm{t}$, very close to that suggested by the modelling in $2002^{4}$.

\subsubsection{Hydrometallurgical Applications of Microwave Heating}

As well as comminution, the early review papers identified applications of microwave treatment to enhance the performance of hydrometallurgical processes. Through collaboration with my PhD student Mohammad Al-Harahsheh and Professor Steven Bradshaw at Stellenbosch University this subject was examined in detail over a period of several years including a well cited review published in 2003 [6]. A number of papers in the literature claimed the presence of so called non- thermal microwave effects, observations which could not be explained by temperature measurement alone. Together with Steven Bradshaw and Wilhelm Louw from Stellenbosch Mohammad, myself and other colleagues from Nottingham demonstrated for the first time these non- thermal effects were actually explained by selective heating of the mineral particles due to their having a higher conductivity than the leaching solution. Thus, their temperature was higher than the bulk solution leading to more rapid dissolution [12]. Further work was performed to determine the impact of microwave assistance on other leaching systems, including making clear recommendations for the scale up of the technology $[15,16,20]$.

\subsubsection{Microwave Processing of Coal}

Nottingham University has a long history of coal research going back over 100 years ${ }^{5}$. Given the large energy consumption associated with production of pulverised fuel (PF) for power generation it was a logical step to consider applying some of the knowledge gained in microwave fracture of metal ores to coal. A collaboration with Prof Edward Lester and our joint PhD student Chris Dodds demonstrated for the first time that the energy required for PF production could be significant reduced at microwave energy inputs significantly less than $1 \mathrm{kWh} / \mathrm{t}$ [9] and also the impacts of different coal ranks on the outcome of the treatment [11]. Further work carried out with colleagues from

\footnotetext{
${ }^{4}$ see PhD thesis Alex Ure for details, currently unpublished 5 https://nottingham.ac.uk/manuscriptsandspecialcollections/collectionsindepth/businessrecords/mining. aspx
} 
Nottingham and from Penn State university in the USA showed that even under high pressure microwaves could create significant structural damage in coal offering the opportunity for enhanced $\mathrm{CO}_{2}$ storage [21].

Microwaves have also been shown to be an excellent way of making coke from noncoking coals through ultra-rapid graphitisation of the coal macerals through thermal runaway or the exponential increase in dielectric loss with temperature [71].

\subsubsection{Microwave Sorting of Ores}

It is well established that grinding ores is highly energy intensive; as well as using microwave energy to fracture ores it is also possible to use microwaves to identify which rock particles have valuable metal phases (hot sulphides) in them and which are totally transparent (transparent gangue). Subsequently, the use of thermal cameras can distinguish the hot from the cold rocks and provide the basis for a separation. Although unpublished I first identified this concept in the mid-1990s as part of work on microwave induced fracture. However, it was work at the University of Queensland which identified that in a typical porphyry copper ore crushed to less than $100 \mathrm{~mm}$, only $30-40 \%$ of particles had copper sulphide phases in them with the rest being barren ${ }^{6}$. When these 2 ideas were combined the concept of microwave sorting was introduced. As would be expected the impact of ore texture and mineralogy will impact the outcome of microwave sorting and this was investigated by one of my PhD students, Becca John and through collaboration with Imperial College, London [26].

Through funding from Rio Tinto, the concept of microwave enhanced sorting was developed into one of the largest throughput microwave processing plants ever built at Kennecott Copper Mine, USA where the concept of microwave induced sorting was demonstrated on over 15,500 tonnes of ore at $150 \mathrm{t} / \mathrm{hr}$. Work also performed showed how the performance of the industrial scale system could be predicted through lab scale tests [30, 31, 32]. Images of the plant at Kennecott are shown in Figure 4. This project was a multi-disciplinary collaboration between a team at Nottingham led by me, Jenike and Johansson USA, materials handling experts, e2v, microwave engineers,

\footnotetext{
${ }^{6}$ N. Djordjevic, Recovery of Copper Sulphide Mineral Grains at Coarse Rock Fragment Size, Minerals Engineering, Vol, 64, PP 131-138.
} 
and Tomra Sorting, ore sorting experts. The total investment in the plant shown in Figure 4 was over US\$30m.

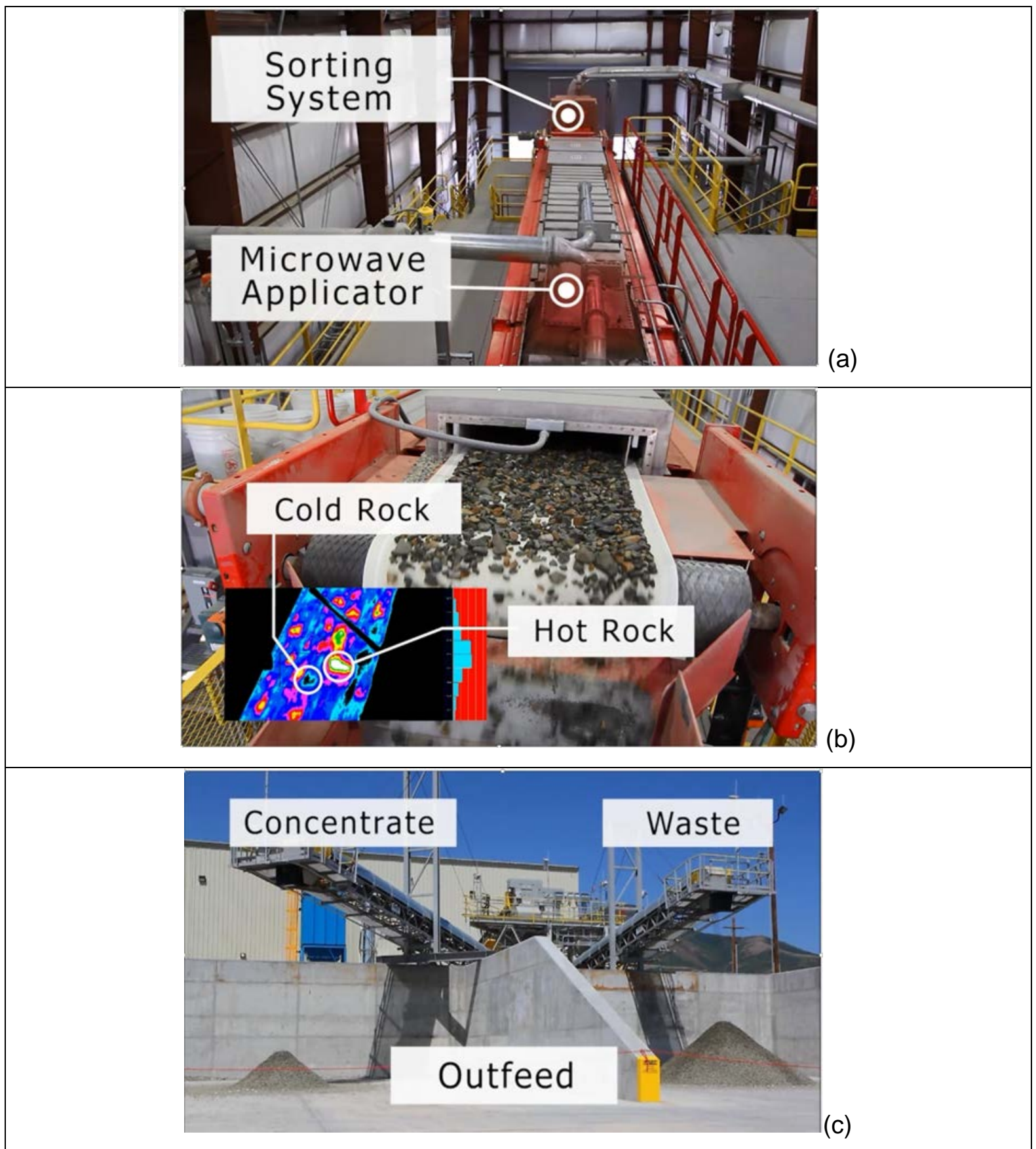

Figure 4: Microwave based sorting system showing (a) microwave applicator designed by Kingman, Dimitrakis and Dodds ${ }^{7}$, (b) the principle of separation showing cold and hot rock after microwave heating and (c) the impact of the process on downstream plant feed with waste rock no longer being transported to the grinding circuit.

\footnotetext{
${ }^{7}$ See USD738943S for details.
} 


\subsubsection{Microwave Expansion of Vermiculite}

Vermiculite is the name given to a group of minerals which contain layers of hydrated sheet silicates which contain layers of water in their internal structure. The main uses of vermiculite, in the expanded form, are horticulture, construction and in friction products as it is highly insulating. These insulating properties lead to extremely high energy consumptions for the expansion, often over $1500 \mathrm{kWh} / \mathrm{t}$ of material. Together with Ola Folorunso a PhD student supervised by Chris Dodds, Georgios Dimitrakis and myself, we demonstrated that vermiculite could be efficiently and controllably expanded through microwave heating [23], that the process was sensitive to the mineralogy of the vermiculite minerals (further collaboration with Ofonime Udoudo and Alex Ure) [24] and that the dielectric properties of the system influenced the overall design of the industrial processing system [25]. The IP developed in the project was protected in the form of a patent ${ }^{8}$ which was subsequently licenced to $\mathrm{e} 2 \mathrm{v}$ who built a production machine at Sinclair's in Gainsborough, Lincolnshire, UK. An image of the first sack of vermiculite produced from this machine is shown in Figure 5. Unfortunately, no further machines were sold due to capital cost issues.

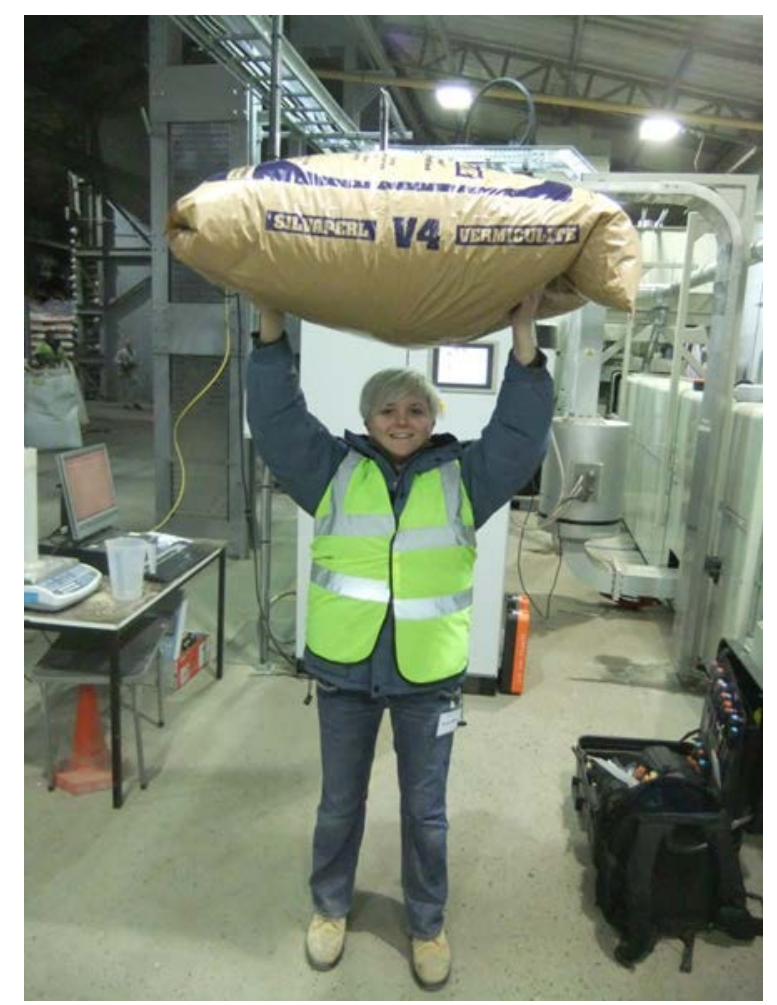

Figure 5: First commercially Produced Sack of Microwave Exfoliated Vermiculite

Manufactured at Sinclair's, Gainsborough, UK in 2012.

\footnotetext{
8 US2012088950A for more details
} 


\subsubsection{Microwave Processing of Oil Contaminated Drill Cuttings}

Oil contaminated drill cuttings arise from drilling and exploration activities. The drill bits use drilling fluid to lubricate the bit and transport the cuttings back to the surface. Drill fluids can be either water based or oil based, oil based often being preferred due to superior properties. UK Environmental legislation stipulates that for off shore disposal in the North Sea (UK's main production fields are found in the North Sea) the oil content of the discharged cuttings needs to be less than $1 \%$ oil. In 2003, in collaboration with Colin Snape at Nottingham, a researcher (now academic) John Robinson and our PhD student Hui Shang we investigated the use of microwave treatment to thermally desorb or steam strip the oil from the cuttings through highly selective heating of the water within the shale structure [57]. Following further funding won from BP, Shell and British Gas a continuous process was developed protected by a patent ${ }^{9}$ where Steven Bradshaw from Stellenbosch University and Michael Bradley from Greenwich University were also joint inventors. The development and details of the system and its operation are given in [58, 59, 22, 60, 61, and 67]. In addition, through the work of several PhD students, Abdul Saeid and Chenbo Yi (jointly supervised by myself with John Robinson) the same system was applied to the treatment of low boiling point hydrocarbon contaminated soils $[68,74]$.

In 2008 funding and engineering support was found from NOV Brandt to commercialise the technology and images of the first incarnation of the system operating in a drill cuttings treatment plant in the UK are in Figure 6.

Unfortunately, after significant process trials and treatment of many tonnes of material the concept had to be re-developed as this belt based system was too sensitive to water content of the feed with water contents of over $20 \%$ leading to incomplete treatment. The belt based system was also susceptible to arcing which is highly undesirable in an area that contains hydrocarbon vapours. Subsequently a new technology was developed which relies on extrusion and this is protected by a patent ${ }^{10}$ and this continues to be developed to this day.

\footnotetext{
9 US2010200300A

10 US2014332366A
} 


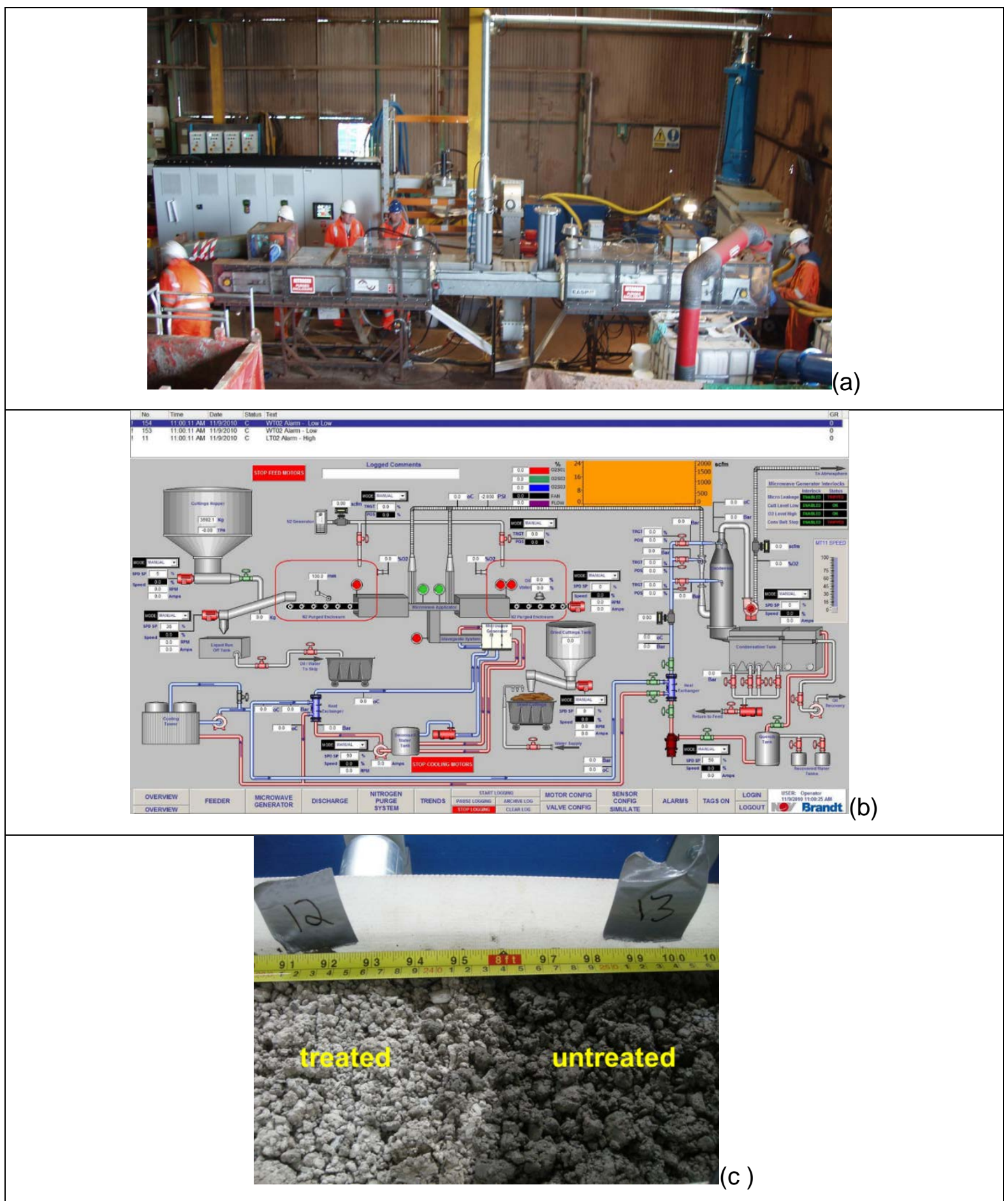

Figure 6 (a) First Industrial Incarnation of Microwave Based System for Processing Oil Contaminated Drilling Wastes, (b), the process control mimic and (c) treated and untreated material.

\subsubsection{Microwave Pyrolysis}

According to Scopus one of the largest areas of microwave publication in 2017 is in microwave pyrolysis ${ }^{11}$. Early work in this area was performed at Nottingham through a PhD student I jointly supervised with John Robinson and Colin Snape, Hassan Al-

\footnotetext{
${ }^{11}$ www.scopus.com
} 
Sayeghy [66]. Further work with other Nottingham collaborators showed that microwave pyrolysis was potentially more controllable than conventional heated systems [73]. Further work with another PhD student Mohammad Adam, again jointly supervised by John Robinson showed that fluidised beds may offer a useful route to scale up $[75,76]$.

Related collaborative studies are reported on Jordanian oil shales and other oil bearing oil sands [64, 72] and also pyrolysis of pecan nutshells for waste water treatment [81].

\subsection{Other Applications of Microwave Heating Technology}

One of the true advantages of microwave technology is flexibility, with significant heating possible in any material that has some degree of conductivity or dielectric loss. So far this summary has focused on my major areas of activity in minerals and mining and energy applications. However, I have also made significant contributions to a number of other studies across numerous application areas. In every case these are collaborative and my contribution was typically related to understanding the interaction of the electromagnetic waves with the material, how this effect could be optimised and where appropriate how it could be scaled up.

Applications are detailed below, with collaborators listed as co-authors on each of the papers.

1. Separation of oil-water emulsions $[69,70]$

2. Recycling of carbon fibre composites [10]

3. Ultra-rapid synthesis of refractory carbides [35, 44, 46, 63]

4. Dielectric spectroscopy for determination of water co-ordination in ionic liquids [37], systems to measure the dielectric properties of water at high temperature and pressure [38], dielectric properties of free radical initiators in polymer synthesis [45], dielectric properties of nano-particles [47], AFM based electrical description of materials [56], dielectric properties of plants [78]

5. Understanding microwave heating for chemical synthesis [40, 44]

6. Microwave enhanced polymer processing $[48,50,51,53]$

7. Processing of electric arc furnace dusts $[52,85]$

8. Ultra-rapid synthesis of metal organic frameworks [54,55]

9. Microwave applications in solid-state inorganic synthesis [49] 
10. Microwave applications in energy efficient treatment of wastes [77]

11. Microwave processing of concrete $[79,80]$ 


\subsection{Summary of Most Significant Research Contributions}

The common theme of my research relates to understanding the interaction of microwave energy with materials and how this understanding relates to the development of large scale industrial microwave processing systems.

Critical is an understanding of the dielectric properties of the heated materials and how they change with the local conditions, how this impacts the process on a micro-scale (selective heating) and also the design of heating cavities for processing (macroscale). These advances have been driven through collaboration, in every case my work alone would not have been enough to scale up microwave technology, but it was my realisation (which now seems obvious) 15 or more years ago that multidisciplinarity was essential to the successful scale up of this technology. I have also contributed significantly in proof of concept studies, but studies which are unlike the majority published by other workers in that the role of microwave heating is well understood, the materials are carefully and correctly characterised and where consideration is given at all times to the techno-economic analysis of the processes concerned. Studies where the cavities for heating are well understood and where the energy transfer to the sample can be calculated reliably.

More specifically, the contribution of my work can be determined through my leadership of the development of four microwave processes towards commercial scale, including two of the largest (if not the largest) throughput industrial microwave processes ever built. In any industry sector other than mining, these would be considered as huge.

Many organisations have benefited commercially from these projects, with jobs created and maintained, and major capital equipment sales across the globe. I estimate (conservatively) that approximately US\$150M has been invested in projects relating to research led by me.

- Microwave Assisted Comminution: Undoubtedly my most important work has been in microwave assisted comminution and along with the work on sorting has delivered possibly the only two technologies globally with potential to make significant and step change impacts on comminution energy reduction. My role here was not just technical but also commercial and I was responsible 
for driving investment of over $\$ 50 \mathrm{M}$ into the project by the sponsor as well as the creation of key parts of the supply chain in microwave engineering $(\mathrm{e} 2 \mathrm{v})$ and bulk solids handling (Jenike and Johansson). The work produced a number of great PhD graduates who now go on to develop their own careers and a significant amount of IP. At the point of writing, work is underway to enable pilot demonstration for the technology on an industrial mine site, however, ultimately the work also produced a plant able to process $150-175 \mathrm{t} / \mathrm{hr}$ or material or around $50 \mathrm{Kg} / \mathrm{s}$.

- Microwave Enhanced Sorting: This research shares many similarities with the work on microwave assisted comminution. It had roots which grew from a fundamental understanding of the interaction of microwave energy with rocks and ores, the scale up methodologies employed were similar and they shared commonality. The investments made by the sponsor were very large (>>US\$75M) and they both delivered step change in the efficiency of a mineral processing flowsheet efficiency. The mineralogy and texture of the ore was fundamental to the successful application of the technology. However, the way that microwave energy was used to create the desired effect was quite different with slow, controlled heating being required compared to the rapidly induced thermal stress and strain required for comminution. It is this controllability and the knowledge of how to design controllability into microwave heating processes (and at very large scale) which is the key achievement here as the technology only works if every particle receives exactly the same dose of energy.

- Microwave Processing of Drill Cuttings: There is no doubt that this project again has roots in my work in mining, with many of the requirements of developing process for oil and gas are similar to mining; the need for 24/7 reliability, inherent process safety and maintainability, flexible (to some degree) in terms of feed properties. The supply chain developed, the licence of the technology and the development of further design concepts following field evaluation were all key parts of the research and development process but in each case the success was based on the earlier research led by myself and the process was developed based on the methodologies shown in Figures 2a-c again developed by myself, Chris Dodds and e2v 
- Microwave Exfoliation of Vermiculite: Possibly on paper the easiest of the applications as the feed material was most consistent and the throughputs the smallest, however, this project was the first to operate commercially in a factory environment. Possibly, the most important aspect of the work, however, is the value it has served as a case study presented at numerous industrial workshops around the world of where the value proposition for microwave technology can be, how it can be developed and what is required to realise it. 
Appendix 1: Lists of Publications included in this Submission and Referred to in Chapters Two and Three

Total citations for each article as of $29^{\text {th }}$ January 2018 are found in brackets after the reference.

1. Kingman, S.W., Rowson, N.A. Microwave treatment of minerals - A review (1998) Minerals Engineering, 11 (11), pp. 1081-1087. (157)

2. Kingman, S.W., Vorster, W., Rowson, N.A. The influence of mineralogy on microwave assisted grinding (2000) Minerals Engineering, 13 (3), pp. 313-327. (86)

3. Vorster, W., Rowson, N.A., Kingman, S.W. The effect of microwave radiation upon the processing of Neves Corvo copper ore (2001) International Journal of Mineral Processing, 63 (1), pp. 29-44. (50)

4. Sahyoun, C., Kingman, S.W., Rowson, N.A. The effect of heat treatment on chalcopyrite (2003) Physical Separation in Science and Engineering, 12 (1), pp. 23-30. (31)

5. Whittles, D.N., Kingman, S.W., Reddish, D.J. Application of numerical modelling for prediction of the influence of power density on microwaveassisted breakage (2003) International Journal of Mineral Processing, 68, pp. 71-91. (64)

6. Al-Harahsheh, M., Kingman, S.W. Microwave-assisted leaching - a review (2004) Hydrometallurgy, 73, pp. 189-203. (170)

7. Kingman, S.W., Jackson, K., Cumbane, A., Bradshaw, S.M., Rowson, N.A., Greenwood, R. Recent developments in microwave-assisted comminution (2004) International Journal of Mineral Processing, 74, pp. 71-83. (83)

8. Kingman, S.W., Jackson, K., Bradshaw, S.M., Rowson, N.A., Greenwood, R. An investigation into the influence of microwave treatment on mineral ore comminution (2004) Powder Technology, 146, pp. 176184. (64)

9. Lester, E., Kingman, S.W.The effect of microwave pre-heating on five different coals (2004) Fuel, 83, pp. 1941-1947. (64)

10. Lester, E., Kingman, S.W., Wong K. H., Rudd, C., Pickering, S., Hilal, N. Microwave heating as a means for carbon fibre recovery from polymer 
composites: a technical feasibility study (2004) Materials Research

Bulletin, 39, pp. 1549-1556. (42)

11. Lester, E., Kingman, S.W., Dodds, C. Increased coal grindability as a result of microwave pre-treatment at economic energy inputs (2005) Fuel, 84, pp. 423-427. (41)

12. Al-Harahsheh, M., Kingman, S.W., Hankins, N., Somerfield, C., Bradshaw, S., Louw, W. The influence of microwaves on the leaching kinetics of chalcopyrite (2005) Minerals Engineering, 18, pp. 1259-1268. (27)

13. Jones, D.A., Kingman, S.W., Whittles, D.N., Lowndes, I.S. Understanding microwave assisted breakage (2005) Minerals Engineering, 18, pp. 659669. (73)

14. Whittles, D.N., Kingman, S.W., Lowndes, I.S., Griffiths, R. An investigation into the parameters affecting mass flow rate of ore material through a microwave continuous feed system (2005) Advanced Powder Technology, 16, no. 6, pp. 585-609. (8)

15. Al-Harahsheh, M., Kingman, S., Bradshaw, S. The reality of non-thermal effects in microwave assisted leaching systems? (2006) Hydrometallurgy, 84, pp. 1-13 (20)

16. Al-Harahsheh, M., Kingman, S., Bradshaw, S. Scale up possibilities for microwave leaching of chalcopyrite in ferric sulphate (2006) International Journal of Mineral Processing, 80, pp. 198-204. (12)

17. Kingman, S.W. Recent developments in microwave processing of minerals (2006) International Materials Reviews (invited review paper), 51 , no. 1, pp. 1-12. (64)

18. Bradshaw, S., Louw, W., Van der Merwe, C., Reader, H., Kingman, S., Celuch, M., Kijewska, W. Techno-economic considerations in the commercial microwave processing of mineral ores (2007) Journal of Microwave Power and Electromagnetic Energy, 40, Vol 4, pp. 228-240. (18)

19. Jones, D.A., Kingman, S.W., Whittles, D.N., Lowndes, I.S. The influence of microwave energy delivery method on strength reduction in ore samples (2007) Chemical Engineering and Processing, 46 (4), pp. 291299. (47) 
20. Al-Harahsheh, M., Kingman, S.W. The influence of microwaves on the leaching of sphalerite in ferric chloride (2007) Chemical Engineering and Processing, 47, pp. 1246-1251. (28)

21. Jones, A., Robinson, J., Halleck, P.M., Mathews, J.P., Kingman .S.W. Inducing fractures and increasing cleat apertures in a bituminous coal under isotropic stress via application of microwave energy (2011) International Journal of Coal Geology, 88 (1), pp. 75-82. (33)

22. Pereira, I.S.M., Robinson, J.P., Kingman, S.W. Effect of agglomerate size on oil removal during microwave treatment of oil contaminated drill cuttings (2011) Industrial and Engineering Chemistry Research, 50 (16), pp. 9727-9734. (2)

23. Folorunso, O., Dodds, C., Dimitrakis, G., Kingman, S.W. Continuous energy efficient exfoliation of vermiculite through microwave heating (2012) International Journal of Mineral Processing, 114-117, pp. 69-79.

24. Udoudo, O., Folorunso, O., Dodds, C., Kingman, S., Ure, A. Understanding the performance of a pilot vermiculite exfoliation system through process mineralogy (2015) Minerals Engineering, 82, pp. 84-91. (1)

25. Katrib, J. , Folorunso, O., Dodds, C., Dimitrakis, G., Kingman, S.W. Improving the design of industrial microwave processing systems through prediction of the dielectric properties of complex multi-layered materials (2015) Journal of Materials Science, 50 (23), pp. 7591-7599. (2)

26.John, R.S., Batchelor, A.R., Ivanov, D., Udoudo, O.B., Jones, D.A., Dodds, C., Kingman, S.W. Understanding microwave induced sorting of porphyry copper ores (2015) Minerals Engineering, 84, pp.7787. (11)

27. Batchelor, A.R., Jones, D.A., Plint, S., Kingman, S.W. Deriving the ideal ore texture for microwave treatment of metalliferous ores (2015) Minerals Engineering, 84, pp. 116-129. (5)

28. Monti, T., Tselev, A., Udoudo, O., Ivanov, I.N., Dodds, C., Kingman, S.W. High-resolution dielectric characterization of minerals: A step towards understanding the basic interactions between microwaves and rocks (2016) International Journal of Mineral Processing, 151, pp. 8-21. (4) 
29. Batchelor, A, R., Plint, S., Kingman, S.W. Increasing the grind size for effective liberation and flotation of a porphyry copper ore by microwave treatment (2016) Minerals Engineering, 94, pp. 61-75. (4)

30. Batchelor, A.R., Ferrari-John, R.S., Katrib, J., Udoudo, O., Jones, D.A., Dodds, C., Kingman, S.W. Pilot scale microwave sorting of porphyry copper ores: Part 1 - Laboratory investigations (2016) Minerals Engineering, 98, pp. 303-327. (2)

31. Batchelor, A.R., Ferrari-John, R.S., Dodds, C., Kingman, S.W. Pilot scale microwave sorting of porphyry copper ores: Part 2 - Pilot plant trials (2016) Minerals Engineering, 98, pp. 328-338. (0)

32. Ferrari-John, R.S., Batchelor, A.R., Katrib, J., Dodds, C., Kingman, S.W. Understanding selectivity in radio frequency and microwave sorting of porphyry copper ores (2016) International Journal of Mineral Processing, 155, pp. 64-73. (0)

33. Buttress, A.J., Katrib, J., Jones, D.A., Batchelor, A.R., Craig, D.A., Royal, T.A., Dodds, C., Kingman, S.W. Towards large scale microwave treatment of ores: Part 1 - Basis of design, construction and commissioning (2017) Minerals Engineering, 109, pp.169-183. (4)

34. Batchelor, A.R., Buttress, A.J., Jones, D.A., Katrib, J., Way, D., Chenje, T., Stoll, D., Dodds, C., Kingman, S.W. Towards large scale microwave treatment of ores: Part 2 - Metallurgical testing (2017) Minerals Engineering, 111, pp. 5-24. (2)

35. Vallance, S. R., Kingman, S.W, Gregory, D. H. Ultrarapid materials processing: synthesis of tungsten carbide on subminute timescales (2007) Advanced Materials, 19, pp. 138-142. (30)

36. Vallance, S.R., Kingman, S., Gregory, D.H. Ultra-rapid processing of refractory carbides; 20 s synthesis of molybdenum carbide, $\mathrm{Mo}_{2} \mathrm{C}$ (2007) Chemical Communications, 7, pp. 742-744. (25)

37.Dimitrakis, G., Villar-Garcia, I.J., Lester, E., Licence, P., Kingman, S. Dielectric spectroscopy: A technique for the determination of water coordination within ionic liquids (2008), Physical Chemistry Chemical Physics, 10, pp. 2947-2951. (24)

38. Dimitrakis, G., George, M., Poliakoff, M., Harrison, I., Robinson, J.P., Kingman, S.W., Lester, E., Gregory, A.P., Lees, K. A system for traceable measurement of the microwave complex permittivity of liquids at high 
pressure and temperatures (2009) Measurement Science \& Technology, 20 (4). (9)

39.Robinson, J.P., Kingman, S.W., Snape, C.E., Barranco, R., Shang, H., Bradley, M.S.A., Bradshaw, S.M. Remediation of oil-contaminated drill cuttings using continuous microwave heating (2009) Chemical Engineering Journal, 152 , p. 458-463. (26)

40. Robinson, J.P., Kingman, S.W., Irvine, D., Licence, P., Smith, A., Dimitrakis, G., Obermayer, D., Kappe, C.O. Electromagnetic simulations of microwave heating experiments using reaction vessels made out of silicon carbide (2010) Physical Chemistry Chemical Physics, 12 (36), p. 10793-10800. (64)

41. Robinson, J.P., Kingman, S.W., Irvine, D., Licence, P., Smith, A., Dimitrakis, G., Obermayer, D., Kappe, C.O. Understanding microwave heating effects in single mode type cavities-theory and experiment (2010) Physical Chemistry Chemical Physics, 12 (18), p. 4750-4758. (23)

42. Smith A.D., Lester, E.H., Thurecht, K.J., El Harfi, J., Dimitrakis, G., Kingman, S.W., Robinson, J.P., Irvine, D. Dielectric Properties of FreeRadical Polymerizations: Molecularly Symmetrical Initiators during Thermal Decomposition (2010) Industrial \& Engineering Chemistry Research, 49 (4), p. 1703-1710. (17)

43. Smith A.D., Lester, E.H., Thurecht, K.J., Kingman, S.W., El Harfi, J., Dimitrakis, G., Robinson, J.P., Irvine, D. Temperature Dependence of the Dielectric Properties of 2,2'-Azobis(2-methyl-butyronitrile) (AMBN) (2010) Industrial \& Engineering Chemistry Research, 49 (6), p. 3011-3014. (13)

44. Carassiti, L., Jones, A., Harrison, P., Dobson, P.S., Kingman, S.W., MacLaren, I., Gregory, D.H. Ultra-rapid, sustainable and selective synthesis of silicon carbide powders and nanomaterials via microwave heating (2011) Energy and Environmental Science, 4, pp. 1503-1510.

45. El Harfi, J., Kingman, S.W., Dimitrakis, G., Robinson, J.P., Irvine, D.J. Dielectric properties of free radical initiators-investigation of thermal decomposition products (2012) Industrial and Engineering Chemistry Research, 51 (49), pp. 15811-15820. (6)

46. Vallance, S.R., Kitchen, H.J., Ritter, C., Kingman, S.W., Dimitrakis, G., Gregory, D.H. Probing the microwave interaction mechanisms and 
reaction pathways in the energy-efficient, ultra-rapid synthesis of tungsten carbide (2012) Green Chemistry, 14 (8), pp. 2184-2192. (7)

47. Chang, H., Dimitrakis, G., Xu, F., Yi, C., Kingman, S.W., Zhu, Y. Microwave dielectric properties of inorganic fullerene-like tungsten disulfide nanoparticles (2013) Chemical Physics Letters, 555, pp. 159-163. (0)

48. Adlington, K., Jones, G.J., El Harfi, J., Dimitrakis, G., Smith, A., Kingman, S.W., Robinson, J.P., Irvine, D.J. Mechanistic investigation into the accelerated synthesis of methacrylate oligomers via the application of catalytic chain transfer polymerization and selective microwave heating (2013) Macromolecules, 46 (10), pp. 3922-3930. (10)

49. Kitchen, H.J., Vallance, S.R., Kennedy, J.L., Tapia-Ruiz, N., Carassiti, L., Harrison, A., Whittaker, A.G., Drysdale, T.D., Kingman, S.W., Gregory, D.H. Modern microwave methods in solid-state inorganic materials chemistry: From fundamentals to manufacturing (2014) Chemical Reviews, 114 (2), pp. 1170-1206. (93)

50. Nguyen, N.T., Greenhalgh, E., Kamaruddin, M.J., El Harfi, J., Carmichael, K., Dimitrakis, G., Kingman, S.W., Robinson, J.P., Irvine, D.J. Understanding the acceleration in the ring-opening of lactones delivered by microwave heating (2014) Tetrahedron, 70 (4), pp. 996-1003. (6)

51. Adlington, K., McSweeney, R., Dimitrakis, G., Kingman, S.W., Robinson, J.P., Irvine, D.J. Enhanced 'in situ' catalysis via microwave selective heating: Catalytic chain transfer polymerisation (2014) RSC Advances, 4 (31), pp. 16172-16180. (7)

52. Al-Harahsheh, M., Kingman, S., Al-Makhadmah, L., Hamilton, I.E. Microwave treatment of electric arc furnace dust with PVC: Dielectric characterization and pyrolysis-leaching (2014) Journal of Hazardous Materials, 274, pp. 87-97. (25)

53. Deng, E., Nguyen, N.T., Hild, F., Hamilton, I.E., Dimitrakis, G., Kingman, S.W., Lau, P.-L., Irvine, D.J. Molecular differentiated initiator reactivity in the synthesis of poly(caprolactone)-Based hydrophobic homopolymer and amphiphilic core corona star polymers (2015) Molecules, 20, pp. 2013120145. (0)

54. Laybourn, A., Katrib, J., Palade, P.A., Easun, T.L., Champness, N.R., Schröder, M., Kingman, S.W. Understanding the electromagnetic interaction of metal organic framework reactants in aqueous solution at 
microwave frequencies (2016) Physical Chemistry Chemical Physics, 18 (7), pp. 5419-5431. (6)

55. Laybourn, A., Katrib, J., Ferrari-John, R.S., Morris, C.G., Yang, S., Udoudo, O., Easun, T.L., Dodds, C., Champness, N.R., Kingman, S.W., Schröder, M. Metal-organic frameworks in seconds via selective microwave heating (2017) Journal of Materials Chemistry $A, 5,16$, pp. 7333-7338. (5)

56. Monti, T., Udoudo, O.B., Sperin, K.A., Dodds, C., Kingman, S.W., Jackson, T.J. Statistical Description of Inhomogeneous Samples by Scanning Microwave Microscopy (2017) IEEE Transactions on Microwave Theory and Techniques, 65, no.6, pp. 2162-2170. (0)

57. Shang, H., Snape, C.E., Kingman, S.W., Robinson, J.P. Treatment of oilcontaminated drill cuttings by microwave heating in a high-power singlemode cavity (2005) Industrial and Engineering Chemistry Research, 44, p. 6837-6844. (25)

58. Shang, H., Snape, C.E., Kingman, S.W., Robinson, J.P. Microwave treatment of oil-contaminated North Sea drill cuttings in a high power multimode cavity (2006) Separation \& Purification Technology, 49, p. 8490. (41)

59. Shang, H., Robinson, J. P., Kingman, S. W., Snape, C. E., Wu, Q. Theoretical study of microwave enhanced thermal decontamination of oil contaminated waste (2007) Chemical Engineering and Technology, 30, no. 1, p. 121-130. (10)

60. Shang, H., Kingman, S.W., Snape, C.E., Robinson, J.P. Reactors effects on microwave decontamination of oily wastes in a multimode cavity (2007) Industrial and Engineering Chemistry Research, 46, pp. 48114818. (5)

61. Robinson, J. P., Snape, C. E., Kingman, S. W., Shang, H. Thermal desorption and pyrolysis of oil contaminated drill cuttings by microwave heating (2008) Journal of Analytical and Applied Pyrolysis, 81 (1), p. 27 32. (23)

62. Robinson, J. P., Kingman, S. W., Onobrakpeya, O. Microwave-assisted stripping of oil contaminated drill cuttings (2008) Journal of Environmental Management, 88 (2), p. 211-218. (31) 
63. Vallance, S.R., Round, D.M., Ritter, C., Cussen, E. J., Kingman, S.W., Gregory, D.H. Ultrarapid microwave synthesis of superconducting refractory carbides (2009) Advanced Materials, 21 (44), p. 4502-4504. (15)

64. Al-Harahsheh, M., Kingman, S.W., Abdurrahman, S., Robinson, J., Dimitrakis, G., Alnawafleh, H. Dielectric properties of Jordanian oil shales (2009) Fuel Processing Technology, 90 (10), p. 1259-1264. (18)

65. Robinson, J.P., Kingman, S.W., Snape, C.E., Shang, H., Barranco, R., Saeid, A. Separation of polyaromatic hydrocarbons from contaminated soils using microwave heating (2009) Separation and Purification Technology, 69 (3), p. 249-254. (29)

66. Robinson, J.P., Kingman, S.W., Barranco, R., Snape, C.E., Al-Sayegh, H. Microwave Pyrolysis of Wood Pellets (2010) Industrial \& Engineering Chemistry Research, 49 (2), p. 459-463. (62)

67. Robinson, J.P., Kingman, S.W., Snape, C.E., Bradshaw, S.M., Bradley, M.S.A., Shang, H., Barranco, R. Scale-up and design of a continuous microwave treatment system for the processing of oil-contaminated drill cuttings (2010) Chemical Engineering Research \& Design, 88 (2A), p. 146-154. (30)

68. Robinson, J.P., Kingman, S.W., Lester, E.H., Yi, C. Microwave remediation of hydrocarbon-contaminated soils - Scale-up using batch reactors (2012) Separation and Purification Technology, 96, pp. 12-19. (28)

69. Binner, E.R., Robinson, J.P., Kingman, S.W., Lester, E.H., Azzopardi, B.J., Dimitrakis, G., Briggs, J. Separation of oil/water emulsions in continuous flow using microwave heating (2013) Energy and Fuels, 27 (6), pp. 3173-3178. (12)

70.Binner, E.R., Robinson, J.P., Silvester, S.A., Kingman, S.W., Lester, E.H. Investigation into the mechanisms by which microwave heating enhances separation of water-in-oil emulsions (2014) Fuel, 116, pp. 516-521. (19)

71. Binner, E., Mediero-Munoyerro, M., Huddle, T., Kingman, S., Dodds, C., Dimitrakis, G., Robinson, J., Lester, E. Factors affecting the microwave coking of coals and the implications on microwave cavity design (2014) Fuel Processing Technology, 125, pp. 8-17. (14) 
72. Robinson, J., Binner, E., Saeid, A., Al-Harahsheh, M., Kingman, S. Microwave processing of Oil Sands and contribution of clay minerals (2014) Fuel, 135, pp. 153-161. (13)

73. Robinson, J., Dodds, C., Stavrinides, A., Kingman, S., Katrib, J., Wu, Z., Medrano, J., Overend, R. Microwave pyrolysis of biomass: Control of process parameters for high pyrolysis oil yields and enhanced oil quality (2015) Energy and Fuels, 29 (3), pp. 1701-1709. (18)

74. Buttress, A.J., Binner, E., Yi, C., Palade, P., Robinson, J.P., Kingman, S.W. Development and evaluation of a continuous microwave processing system for hydrocarbon removal from solids (2016) Chemical Engineering Journal, 283, pp. 215-222. (17)

75. Adam, M., Beneroso, D., Katrib, J., Kingman, S., Robinson, J.P. Microwave fluidized bed for biomass pyrolysis. Part I: Process design (2017) Biofuels, Bioproducts and Biorefining, 11 pp. 601-612. (1)

76. Adam, M., Beneroso, D., Katrib, J., Kingman, S., Robinson, J.P. Microwave fluidized bed for biomass pyrolysis. Part II: Effect of process parameters (2017)Biofuels, Bioproducts and Biorefining, 11, pp. 613-624. (0)

77. Appleton, T.J., Colder, R.I., Kingman, S.W., Lowndes, I.S., Read, A.G. Microwave technology for energy-efficient processing of waste (2005) Applied Energy, 81, p. 85-113. (171)

78. Navarrete, A., Mato, R.B., Dimitrakis, G., Lester, E., Robinson, J.R., Cocero, M.J., Kingman, S.W. Measurement and estimation of aromatic plant dielectric properties. Application to low moisture rosemary (2011) Industrial Crops and Products, 33 (3), pp. 697-703. (14)

79. Buttress, A., Jones, A., Kingman, S.W. Microwave processing of cement and concrete materials - towards an industrial reality? (2015) Cement and Concrete Research, 68, pp. 112-123. (14)

80. Buttress, A.J., Jones, D.A., Dodds, C., Dimitrakis, G., Campbell, C.J., Dawson, A., Kingman, S.W. Understanding the scabbling of concrete using microwave energy (2015) Cement and Concrete Research, 75, pp.75-90. (3)

81. Jimenez, G.D., Monti, T., Titman, J.J., Hernandez-Montoya, V., Kingman, S.W., Binner, E.R. New insights into microwave pyrolysis of biomass: Preparation of carbon-based products from pecan nutshells and their 
application in wastewater treatment (2017) Journal of Analytical and Applied Pyrolysis, 124, pp. 113-121. (1)

82. Kingman, S.W., Corfield, G.M., Rowson, N.A., Effect of Microwave Radiation upon the Mineralogy and Magnetic processing of A Norwegian Ilmenite Ore, Magnetic and Electrical Separation Vol. 9, No.3, pp. 131-148 (36)

83. Kingman, S.W., Vorster, W. Rowson, N.A., The effect of microwave radiation on the processing of a Palabora Copper ore (2000), Journal of the SAIMM, Vol. 100, No.3, PP. 197-204. (13)

84. Kingman, S.W., Rowson, N.A., Effect of microwave energy on the magnetic properties of minerals (2000), Journal of Microwave Power and Electromagnetic Energy Vol. 35, No.3, PP 144-150 (17)

85. Al-Harahseh, M., Hamilton, I, Kingman, S.W. Microwave treatment of electric arc furnace dust with Tetrabrombisphenol A: Dielectric characterisation and pyrolysis leaching (2017), Journal of Analytical and Applied Pyrolysis Vol. 128, PP. 168-175 (3) 
86. Williams, O., Lester, E., Kingman, S., Giddings, D., Lormor, S., Eastwick, C. Benefits of dry comminution of biomass pellets in a knife mill (2017) Biosystems Engineering, 160, pp. 42-54.

87. Williams, O., Eastwick, C., Kingman, S., Giddings, D., Lormor, S., Lester, E. Overcoming the caking phenomenon in olive mill wastes (2017) Industrial Crops and Products, 101, pp. 92-102.

88. Monti, T., Udoudo, O.B., Sperin, K.A., Dodds, C., Kingman, S.W., Jackson, T.J. Statistical Description of Inhomogeneous Samples by Scanning Microwave Microscopy (2017) IEEE Transactions on Microwave Theory and Techniques, 65, no.6, pp. 2162-2170.

89. Al-Harahsheh, M., Aljarrah, M., Rummanah, F., Abdel-Latif, K., Kingman, S. Leaching of valuable metals from electric arc furnace dustTetrabromobisphenol A pyrolysis residues (2017) Journal of Analytical and Applied Pyrolysis, 125, pp. 50-60.

90. Al-Harahsheh, M., Al-Otoom, A., Al-Jarrah, M., Altarawneh, M., Kingman, S. Thermal Analysis on the Pyrolysis of Tetrabromobisphenol $A$ and Electric Arc Furnace Dust Mixtures (2017) Metallurgical and Materials Transactions B: Process Metallurgy and Materials Processing Science, pp. 1-16.

91. Williams, O., Newbolt, G., Eastwick, C., Kingman, S., Giddings, D., Lormor, S., Lester, E. Influence of mill type on densified biomass comminution (2016) Applied Energy, 182, pp. 219-231

92. Renshaw, R.C., Robinson, J.P., Dimitrakis, G.A., Bows, J.R., Kingman, S.W.Characterisation of potato crisp effective porosity using microCT (2016) Journal of the Science of Food and Agriculture, pp. 4440-4448 93.Zhao, H., Yang, G., Gao, X., Pang, C.H., Kingman, S.W., Wu, T. $\mathrm{Hg} 0$ Capture over CoMoS/Y-Al2O3 with MoS2 Nanosheets at Low Temperatures (2016) Environmental Science and Technology, 50 (2), pp. 1056-1064

94.Zhao, H., Yang, G., Gao, X., Pang, C., Kingman, S., Lester, E., Wu, T. Hg0-temperature-programmed surface reaction and its application on the investigation of metal oxides for $\mathrm{HgO}$ capture (2016) Fuel 
95. Al-Harahsheh, M., Al-Otoom, A., Al-Makhadmah, L., Hamilton, I.E., Kingman, S., Al-Asheh, S., Hararah, M. Pyrolysis of poly(vinyl chloride) and-electric arc furnacedust mixtures (2015) Journal of Hazardous Materials, 299, pp.425-436

96. Williams, O., Eastwick, C., Kingman, S., Giddings, D., Lormor, S., Lester, E. Investigation into the applicability of Bond Work Index (BWI) and Hardgrove Grindability Index (HGI) tests for several biomasses compared to Colombian la Loma coal (2015), 158, pp. 379-387

97.Zhao, H., Wu, T., He, J., Kingman, S.W., Shi, K., Shen, D., Zhang, Y.Simultaneous removal of SOx and NOx in flue gas at power stations over a Cu/Na-13X zeolite catalyst (2013) Advanced Materials Research, 650, pp. 125-129.

98. Al-Harahsheh, M., Al-Ayed, O., Robinson, J., Kingman, S.W., AlHarahsheh, A., Tarawneh, K., Saeid, A., Barranco, R.Effect of demineralization and heating rate on the pyrolysis kinetics of Jordanian oil shales (2011) Fuel Processing Technology, 92 (9), pp. 1805-1811.

99. Fokeer, S., Lowndes, S., Kingman, S.W. An experimental investigation of pneumatic swirl flow induced by aree lobed helical pipe (2009) International Journal of Heat and Fluid Flow, 30 (2), p. 369-379

100. Fokeer, S., Lowndes, I., Kingman, S.W. An experimental investigation of pneumatic swirl flow induced by a three lobed helical pipe (2009) International Journal of Heat and Fluid Flow, 30 (2), p. 369-379.

101. Pinero-Hernanz, R., Dodds, C., Hyde, J., Garcia-Serna, J., Poliakoff, M., Lester, E., Cocero, M. J., Kingman, S.W., Pickering, S., Wong, K. H., Chemical recycling of carbon fibre reinforced composites in nearcritical and supercritical water (2008) Composites Part A: Applied Science and Manufacturing, 39 (3), p. 454-461.

102. Wang, X., Miles, N. J.,Kingman, S.W Segregation of ultrafine particles in a centrifugal fluidized bed separator (2008) Advanced Powder Technology, 19 (4), p. 335-348.

103. Pinero-Hernanz, R., Garcia-Serna, J., Dodds, C., Hyde, J., Poliakoff, M., Cocero, M. J., Kingman, S.W., Pickering, S., Lester, E. Chemical recycling of carbon fibre composites using alcohols under subcritical and supercritical conditions (2008) Journal of Supercritical Fluids, 46 (1), p. 8392. 
104. Vallance, S. R., Kingman, S.W, Gregory, D. H. Ultrarapid materials processing: synthesis of tungsten carbide on subminute timescales (2007) Advanced Materials, 19, p. 138-142.

105. Petavratzi, E., Kingman, S. W., Lowndes, I. S. Assessment of the dustiness and the dust liberation mechanisms of limestone quarry operations (2007) Chemical Engineering and Processing: Process Intensification, 46 (12), p. 1412-1423.

106. Silvester, S.A., Lowndes, I.S., Kingman, S.W., Arroussi, A. Improved dust capture methods for crushing plant (2007) Applied Mathematical Modelling, 31 (2), p. 311

107. Whittles, D.N., Kingman, S.W., Lowndes, I., Jackson, K. Laboratory and numerical investigation into the characteristics of rock fragmentation (2006) Minerals Engineering, 19 (14), p. 1418-142

108. Hyde, J.R., Lester, E., Kingman, S.W., Pickering, S.,Wong, K.H. Supercritical propanol, a possible route to composite carbon fibre recovery: A viability study (2006) Composites Part A: Applied Science and Manufacturing, 37, p. 2171-2175.

109. Leaper, M.C., Kingman, S.W., Seville, J.P.K. Application of permanent dry high intensity magnetic separation for the processing of spent FCC catalyst (2002) Magnetic and Electricall Separation, 11 (3), pp. 141-153.

110. Greenwood, R., Rowson, N., Kingman, S.W., Brown, G. A new method for determining the optimum dispersant concentration in aqueous grinding (2002) Powder Technology, 123 (2-3), pp. 199-207. 
Appendix 3: Patents on which I am an Inventor

\begin{tabular}{|c|c|c|c|}
\hline \multirow[t]{20}{*}{$\begin{array}{c}\text { Family Number } \\
\text { (US2005236403A) }\end{array}$} & Inventors & $\begin{array}{l}\text { Title: Pre Treatment } \\
\text { of Multi-Phase } \\
\text { Materials using high } \\
\text { filed strength } \\
\text { Electromagnetic } \\
\text { waves }\end{array}$ & $\begin{array}{l}\text { Publication } \\
\text { Numbers }\end{array}$ \\
\hline & Samuel Kingman & & AT380887 \\
\hline & & & AU2003214468 \\
\hline & & & CN1692168 \\
\hline & & & DE60318027 \\
\hline & & & DK1490525 \\
\hline & & & EP1490525 \\
\hline & & & ES2298504 \\
\hline & & & ES2298504 \\
\hline & & & GB200207530 \\
\hline & & & IN03083DN2004 \\
\hline & & & IN241056 \\
\hline & & & JP2005524514 \\
\hline & & & PT1490525 \\
\hline & & & RU2004131862 \\
\hline & & & RU2318028 \\
\hline & & & US2005236403 \\
\hline & & & US7476829 \\
\hline & & & WO03083146 \\
\hline & & & ZA200407952 \\
\hline \multirow[t]{9}{*}{$\begin{array}{l}\text { Family Number } \\
\text { (US2013062264A) }\end{array}$} & Inventors & $\begin{array}{c}\text { Title: Sorting Mined } \\
\text { Material }\end{array}$ & $\begin{array}{l}\text { Publication } \\
\text { Numbers }\end{array}$ \\
\hline & George Dimitrakis & & AP201206375 \\
\hline & Chris Dodds & & AP3239 \\
\hline & Samuel Kingman & & AU2010336011 \\
\hline & & & CA2784608 \\
\hline & & & CN102741686 \\
\hline & & & EP2516997 \\
\hline & & & MX2012007173 \\
\hline & & & PE03202013 \\
\hline
\end{tabular}




\begin{tabular}{|c|c|c|c|}
\hline & & & RU2012131171 \\
\hline & & & US2013062264 \\
\hline & & & US8967384 \\
\hline & & & WO11075768 \\
\hline \multirow[t]{10}{*}{$\begin{array}{l}\text { Family Number } \\
\text { (US2013098807A) }\end{array}$} & Inventors & $\begin{array}{c}\text { Title: Sorting Mined } \\
\text { Material }\end{array}$ & $\begin{array}{l}\text { Publication } \\
\text { Numbers }\end{array}$ \\
\hline & Grant Wellwood & & AP201206616 \\
\hline & Samuel Kingman & & AU2011245066 \\
\hline & & & CA2797427 \\
\hline & & & CL2012003013 \\
\hline & & & CN102869459 \\
\hline & & & PE08312013 \\
\hline & & & US2013098807 \\
\hline & & & US8957340 \\
\hline & & & WO11134009 \\
\hline \multirow[t]{10}{*}{$\begin{array}{l}\text { Family Number } \\
\text { (US2013186992A) }\end{array}$} & Inventors & $\begin{array}{c}\text { Title: Sorting Mined } \\
\text { Material }\end{array}$ & $\begin{array}{l}\text { Publication } \\
\text { Numbers }\end{array}$ \\
\hline & Samuel Kingman & & AP201306747 \\
\hline & Grant Wellwood & & AU2011286164 \\
\hline & Chris Dodds & & AU2015215952 \\
\hline & Georgios Dimitrakis & & CA2806887 \\
\hline & & & CL2013000333 \\
\hline & & & CN103052451 \\
\hline & & & PE11112013 \\
\hline & & & US2013186992 \\
\hline & & & WO12016286 \\
\hline \multirow[t]{10}{*}{$\begin{array}{l}\text { Family Number } \\
\text { (US2014260802A) }\end{array}$} & Inventors & $\begin{array}{c}\text { Title: Processing } \\
\text { Mined Material }\end{array}$ & $\begin{array}{l}\text { Publication } \\
\text { Numbers }\end{array}$ \\
\hline & Samuel Kingman & & AP201407410 \\
\hline & Georgios Dimitrakis & & AU2012289829 \\
\hline & Chris Dodds & & CA2843379 \\
\hline & Grant Wellwood & & CL2014000265 \\
\hline & & & CN103827660 \\
\hline & & & EA201490267 \\
\hline & & & EP2753919 \\
\hline & & & IN01073CN2014 \\
\hline & & & MX2014001262 \\
\hline
\end{tabular}




\begin{tabular}{|c|c|c|c|}
\hline & & & PE09942014 \\
\hline & & & US2014260802 \\
\hline & & & WO13016771 \\
\hline \multirow[t]{13}{*}{$\begin{array}{l}\text { Family Number } \\
\text { (US2014346091A) }\end{array}$} & Inventors & $\begin{array}{c}\text { Title: Processing } \\
\text { Mined Material }\end{array}$ & $\begin{array}{c}\text { Publication } \\
\text { Numbers }\end{array}$ \\
\hline & Samuel Kingman & & AP201407406 \\
\hline & Georgios Dimitrakis & & AU2012289834 \\
\hline & Chris Dodds & & CA2843387 \\
\hline & Grant Wellwood & & CL2014000275 \\
\hline & & & CN103781561 \\
\hline & & & EA201490266 \\
\hline & & & EP2739408 \\
\hline & & & IN01035CN2014 \\
\hline & & & MX2014001261 \\
\hline & & & PE12132014 \\
\hline & & & US2014346091 \\
\hline & & & WO13016774 \\
\hline \multirow[t]{7}{*}{$\begin{array}{l}\text { Family Number } \\
\text { (US2014322106A) }\end{array}$} & Inventors & $\begin{array}{c}\text { Title: Method for the } \\
\text { Treatment of Ore } \\
\text { Material }\end{array}$ & $\begin{array}{l}\text { Publication } \\
\text { Numbers }\end{array}$ \\
\hline & Georgios Dimtrakis & & AU2012334803 \\
\hline & Samuel Kingman & & CA2854865 \\
\hline & Chris Dodds & & CL2014001213 \\
\hline & Erin Hamilton & & PE2059201 \\
\hline & Gary Davis & & US2014322106 \\
\hline & & & WO13067577 \\
\hline \multirow[t]{7}{*}{$\begin{array}{l}\text { Family Number } \\
\text { (US2014291212A) }\end{array}$} & Inventors & $\begin{array}{c}\text { Title: Microwave } \\
\text { Applicator }\end{array}$ & $\begin{array}{l}\text { Publication } \\
\text { Numbers }\end{array}$ \\
\hline & Samuel Kingman & & AU2012334800 \\
\hline & Georgios Dimitrakis & & CA2852330 \\
\hline & Chris Dodds & & CL2014001191 \\
\hline & & & PE05282015 \\
\hline & & & US2014291212 \\
\hline & & & WO13067574 \\
\hline $\begin{array}{l}\text { Family Number } \\
\text { (USD738943S) }\end{array}$ & Inventors & $\begin{array}{l}\text { Title: Vessel for the } \\
\text { Microwave } \\
\text { Treatment of Ore }\end{array}$ & $\begin{array}{l}\text { Publication } \\
\text { Numbers }\end{array}$ \\
\hline
\end{tabular}


Stellenbosch University https://scholar.sun.ac.za

\begin{tabular}{|c|c|c|c|}
\hline & Georgios Dimitrakis & & CN302341604 \\
\hline & Chris Dodds & & IN246488 \\
\hline & Sam Kingman & & IN246489 \\
\hline & & & USD738943 \\
\hline \multirow[t]{5}{*}{$\begin{array}{l}\text { Family Number } \\
\text { (US2015292056A) }\end{array}$} & Inventors & $\begin{array}{c}\text { Title: Apparatus } \\
\text { and a Method for } \\
\text { Treatment of Mined } \\
\text { Material with } \\
\text { Electromagnetic } \\
\text { Radiation }\end{array}$ & $\begin{array}{l}\text { Publication } \\
\text { Numbers }\end{array}$ \\
\hline & Georgios Dimitrakis & & CN104812919 \\
\hline & Samuel Kingman & & PE10102015 \\
\hline & Chris Dodds & & US2015292056 \\
\hline & Aled Jones & & WO14066941 \\
\hline \multirow[t]{6}{*}{$\begin{array}{l}\text { Family Number } \\
\text { (WO14075129A1) }\end{array}$} & Inventors & $\begin{array}{c}\text { Title: An Apparatus } \\
\text { for Treatment of } \\
\text { Mined Material }\end{array}$ & $\begin{array}{l}\text { Publication } \\
\text { Numbers }\end{array}$ \\
\hline & Samuel Kingman & & WO14075129 \\
\hline & Andrew Batchelor & & \\
\hline & Chris Dodds & & \\
\hline & Aled Jones & & \\
\hline & Grant Wellwood & & \\
\hline \multirow[t]{9}{*}{$\begin{array}{l}\text { Family Number } \\
\text { (US2015337410A) }\end{array}$} & Inventors & $\begin{array}{l}\text { Title: Heap } \\
\text { Leaching }\end{array}$ & $\begin{array}{l}\text { Publication } \\
\text { Numbers }\end{array}$ \\
\hline & Georgios Dimitrakis & & AU2013344830 \\
\hline & Paula Palade & & CA2891236 \\
\hline & Juliano Katrib & & CN104919064 \\
\hline & Samuel Kingman & & PE11722015 \\
\hline & Chris Goodes & & US2015337410 \\
\hline & Chris Dodds & & WO14075148 \\
\hline & Grant Wellwood & & \\
\hline & Andrew Batchelor & & \\
\hline \multirow[t]{4}{*}{$\begin{array}{l}\text { Family Number } \\
\text { (US2015314332A) }\end{array}$} & Inventors & $\begin{array}{c}\text { Title: Sorting Mined } \\
\text { Material }\end{array}$ & $\begin{array}{l}\text { Publication } \\
\text { Numbers }\end{array}$ \\
\hline & Georgios Dimitrakis & & CN105122045 \\
\hline & Samuel Kingman & & PE12462015 \\
\hline & Chris Dodds & & US2015314332 \\
\hline
\end{tabular}




\begin{tabular}{|c|c|c|c|}
\hline & Juliano Katrib & & WO14082135 \\
\hline & Andrew Batchelor & & \\
\hline & Aled Jones & & \\
\hline \multirow[t]{6}{*}{$\begin{array}{l}\text { Family Number } \\
\text { (WO14094058A1) }\end{array}$} & Inventors & $\begin{array}{c}\text { Title: A Recovery } \\
\text { Process }\end{array}$ & $\begin{array}{l}\text { Publication } \\
\text { Numbers }\end{array}$ \\
\hline & Samuel Kingman & & WO14094058 \\
\hline & Chris Dodds & & \\
\hline & Aled Jones & & \\
\hline & Andrew Batchelor & & \\
\hline & Grant Wellwood & & \\
\hline \multirow[t]{5}{*}{$\begin{array}{l}\text { Family Number } \\
\text { (WO14094063A1) }\end{array}$} & Inventors & $\begin{array}{l}\text { Title: Treatment of } \\
\text { Mined Material }\end{array}$ & $\begin{array}{l}\text { Publication } \\
\text { Numbers }\end{array}$ \\
\hline & Samuel Kingman & & WO14094063 \\
\hline & Aled Jones & & \\
\hline & Chris Dodds & & \\
\hline & Grant Wellwood & & \\
\hline \multirow[t]{6}{*}{$\begin{array}{l}\text { Family Number } \\
\text { (WO14146172A1) }\end{array}$} & Inventors & $\begin{array}{c}\text { Title: Processing } \\
\text { Mined Material }\end{array}$ & $\begin{array}{l}\text { Publication } \\
\text { Numbers }\end{array}$ \\
\hline & Samuel Kingman & & AU2014234959 \\
\hline & Chris Dodds & & \\
\hline & Paula Palade & & \\
\hline & Rebecca John & & \\
\hline & Georgios Dimitrakis & & WO14146172 \\
\hline \multirow[t]{6}{*}{$\begin{array}{l}\text { Family Number } \\
\text { (WO14205481A1) }\end{array}$} & Inventors & $\begin{array}{c}\text { Title: An Apparatus } \\
\text { and a Method for } \\
\text { Treating Mined } \\
\text { Material }\end{array}$ & $\begin{array}{l}\text { Publication } \\
\text { Numbers }\end{array}$ \\
\hline & Samuel Kingman & & WO14205481 \\
\hline & Chris Dodds & & \\
\hline & Aled Jones & & \\
\hline & Andrew Batchelor & & \\
\hline & Grant Wellwood & & \\
\hline $\begin{array}{l}\text { Family Number } \\
\text { (WO15077817A1) }\end{array}$ & Inventors & $\begin{array}{c}\text { Title: A Method for } \\
\text { Treatment of Mined } \\
\text { Material with }\end{array}$ & $\begin{array}{l}\text { Publication } \\
\text { Numbers }\end{array}$ \\
\hline
\end{tabular}




\begin{tabular}{|c|c|c|c|}
\hline & & $\begin{array}{c}\text { Electromagnetic } \\
\text { Radiation }\end{array}$ & \\
\hline & Samuel Kingman & & WO15077817 \\
\hline & Chris Dodds & & \\
\hline & Aled Jones & & \\
\hline \multirow[t]{3}{*}{$\begin{array}{l}\text { Family Number } \\
\text { (WO15081372A3) }\end{array}$} & Inventors & $\begin{array}{l}\text { Title: Heap } \\
\text { Leaching }\end{array}$ & $\begin{array}{l}\text { Publication } \\
\text { Numbers }\end{array}$ \\
\hline & Samuel Kingman & & W015081372 \\
\hline & Lucy Esdaile & & \\
\hline \multirow[t]{12}{*}{$\begin{array}{l}\text { Family Number } \\
\text { (US2010200300A) }\end{array}$} & Inventors & $\begin{array}{c}\text { Title: } \\
\text { Electromagnetic } \\
\text { Treatment of } \\
\text { Contaminated } \\
\text { Materials }\end{array}$ & $\begin{array}{l}\text { Publication } \\
\text { Numbers }\end{array}$ \\
\hline & John Robinson & & AU2007321014 \\
\hline & Samuel Kingman & & CA2669497 \\
\hline & Colin Snape & & CN101641166 \\
\hline & Michael Bradley & & EP2091673 \\
\hline & Steven Bradshaw & & GB200622595 \\
\hline & & & MX2009005083 \\
\hline & & & MY151739 \\
\hline & & & NO20092253 \\
\hline & & & US2010200300 \\
\hline & & & US8789583 \\
\hline & & & WO08059240 \\
\hline \multirow[t]{4}{*}{$\begin{array}{l}\text { Family Number } \\
\text { (WO08107673A1) }\end{array}$} & Inventors & $\begin{array}{c}\text { Title: A Method of } \\
\text { Separating an Oil } \\
\text { Phase and an } \\
\text { Aqueous Phase }\end{array}$ & $\begin{array}{l}\text { Publication } \\
\text { Numbers }\end{array}$ \\
\hline & Badrul Huda & & EP1970109 \\
\hline & Samuel Kingman & & WO08107673 \\
\hline & Edward Lester & & \\
\hline $\begin{array}{l}\text { Family Number } \\
\text { (GB2463276A) }\end{array}$ & Inventors & $\begin{array}{l}\text { Title: Apparatus } \\
\text { and Method for }\end{array}$ & $\begin{array}{l}\text { Publication } \\
\text { Numbers }\end{array}$ \\
\hline
\end{tabular}




\begin{tabular}{|c|c|c|c|}
\hline & & $\begin{array}{c}\text { Separating a } \\
\text { Multiphase Fluid }\end{array}$ & \\
\hline & & & GB200816267 \\
\hline & & & GB2463276 \\
\hline \multirow[t]{7}{*}{$\begin{array}{l}\text { Family Number } \\
\text { (GB2463275A) }\end{array}$} & Inventors & $\begin{array}{l}\text { Title: Apparatus } \\
\text { and Method for } \\
\text { Separating a } \\
\text { Multiphase Fluid }\end{array}$ & $\begin{array}{l}\text { Publication } \\
\text { Numbers }\end{array}$ \\
\hline & Samuel Kingman & & GB200816266 \\
\hline & John Robinson & & \\
\hline & Badrul Huda & & \\
\hline & James Adams & & GB2463275 \\
\hline & Edward Lester & & \\
\hline & Georgios Dimitrakis & & \\
\hline \multirow[t]{13}{*}{$\begin{array}{l}\text { Family Number } \\
\text { (US2012088950A) }\end{array}$} & Inventors & $\begin{array}{c}\text { Title: Microwave } \\
\text { Processing of } \\
\text { Feedstock, such as } \\
\text { Exfoliating } \\
\text { Vermiculite and } \\
\text { Other Minerals, and } \\
\text { Treating } \\
\text { Contaminated } \\
\text { Materials }\end{array}$ & $\begin{array}{l}\text { Publication } \\
\text { Numbers }\end{array}$ \\
\hline & Chris Dodds & & AU2009329282 \\
\hline & Samuel Kingman & & BRPI0923378 \\
\hline & Georgios Dimitrakis & & CA2747765 \\
\hline & & & CN102300827 \\
\hline & & & EP2376399 \\
\hline & & & GB200823091 \\
\hline & & & IN0145MN2011 \\
\hline & & & JP2012512804 \\
\hline & & & RU2011129310 \\
\hline & & & US2012088950 \\
\hline & & & US8728348 \\
\hline & & & WO10070357 \\
\hline $\begin{array}{l}\text { Family Number } \\
\text { (AR081939A) }\end{array}$ & Inventors & Title: & $\begin{array}{l}\text { Publication } \\
\text { Numbers }\end{array}$ \\
\hline
\end{tabular}




\begin{tabular}{|c|c|c|c|}
\hline & & $\begin{array}{l}\text { A method to expand } \\
\text { mineral material } \\
\text { sandwiched a layer } \\
\text { of water between } \\
\text { the layers } \\
\text { of the mineral, } \\
\text { expander } \\
\text { microwave } \\
\text { particles, a method } \\
\text { for the processing of } \\
\text { raw materials using } \\
\text { microwaves, a } \\
\text { method for applying } \\
\text { microwaves to a } \\
\text { feedstock, process } \\
\text { to produce oil or } \\
\text { gas, a method to } \\
\text { reduce the oil } \\
\text { content in a matrix } \\
\text { contaminated with } \\
\text { hydrocarbons, }\end{array}$ & \\
\hline & Chris Dodds & & AR081939 \\
\hline & Georgios Dimitrakis & & \\
\hline & Samuel Kingman & & \\
\hline $\begin{array}{l}\text { Family Number } \\
\text { (US2014332366A) }\end{array}$ & Inventors & $\begin{array}{l}\text { Title: Treatment of } \\
\text { Hydrocarbon } \\
\text { Containing Materials }\end{array}$ & $\begin{array}{l}\text { Publication } \\
\text { Numbers }\end{array}$ \\
\hline & George Burnett & & AU2013213436 \\
\hline & John Robinson & & CA2862508 \\
\hline & Samuel Kingman & & EP2807231 \\
\hline & Chris Dodds & & GB201201226 \\
\hline & & & GB2498736 \\
\hline & & & US2014332366 \\
\hline & & & WO13110944 \\
\hline
\end{tabular}


Appendix 4: Postdoctoral Researchers and PhD Students Supervised

Postdoctoral and Other Researchers Employed

Postdoctoral Researchers

1. Dr Keith Jackson

2. Dr Aled Jones

3. $\operatorname{Dr}$ S Silvester

4. Dr H Shang

5. Dr R Barranco

6. Dr Andrew Batchelor

7. Dr Mark Leaper

8. Dr Georgios Dimitrakis

9. Dr Paul Blood

10. Dr Steve Plint

11. Dr Chris Dodds

12. Dr Paula Palade

13. Dr Juliano Katrib

14. Dr Adam Buttress

15. Dr Angelique Sklaorov

16. Dr Tamara Monti

17. Dr Ofonime Udoudo

18. Dr lain Hamilton

19. Dr Kevin Adlington

20. Dr Stephen Ison

21. Dr Rebecca John

22. Dr Jose Rodriguez Oyarzun
Microwave Processing of Ores, 2001

Microwave Processing of Ores, 2002

Mineral Processing, 2004

Oil Wastes Processing, 2005

Contaminated Soil treatment, 2006

Microwave Processing of Ores, 2006

Materials Separation, 2006

Electromagnetic Design, 2005

Oil Water Separations, 2006

Materials Characterisation, 2006

Microwave Processing, 2007

Electromagnetic Design, 2008

Electromagnetic Design, 2008

Materials Processing, 2009

Electromagnetic Design, 2010

Electromagnetic Measurements, 2011

Mineral Characterisation, 2012

Materials Chemistry, 2012

Materials Chemistry, 2012

Materials Processing, 2013

Materials Processing, 2015

Electromagnetic Design, 2017

Supervisor of Graduated Doctoral Students

1. Antonio Cumbane

2. Aled Jones

3. Caline Sahyun

4. Bianfang Bai
Graduated 2003

Graduated 2004

Graduated 2004

Graduated 2005 
5. Mohammad Al-Harahsheh

6. Evaggelia Petavratzi

7. Arum Vathavooran

8. Xuesong Wang

9. Christopher Dodds

10. Smeeta Fokker

11. Louisa Groves

12. Hui Shang

13. Simon Vallance

14. Helena Webster

15. Joseph Kobusheshe

16. Peter Wardell

17. Mohd Johari Kamaruddin

18. Geoff Genn

19. Vladimir Jokovic

20. Vladimir Rizmanoski

21. Hassan Al-Sayegh

22. Andrew Batchelor

23. Igor Piereira

24. Chenbo Yi

25. Edward Walker

26. Rebecca John

27. Olaosebikan Folorunso

28. Catherine Clarkson

29. Orla Williams

30. Mohammad Adam

31. Alexander Ure
Graduated 2005

Graduated 2006

Graduated 2006

Graduated 2006

Graduated 2006

Graduated 2006

Graduated 2007

Graduated 2006

Graduated 2008

Graduated 2008

Graduated 2010

Graduated 2011

Graduated 2012

Graduated 2012

Graduated 2012

Graduated 2012

Graduated 2012

Graduated 2012

graduated 2013

Graduated 2013

Graduated 2014

Graduated 2014

Graduated 2015

Graduated 2015

Graduated 2016

Graduated 2016

Graduated 2017 
Appendix 5: Prizes, Awards and Distinctions Related to Research in this Thesis

Note all awards are team prizes except where noted.

- 2000 UK Medal for Excellence in Engineering by a younger engineering, awarded by the Engineering Council (individual)

- 2008 Society of Petroleum Engineers; Environmental Technologies Prize for Microwave Routes for Processing of Drilling Wastes

- 2008 Environmental Technology Award, The Engineer Technology and Innovation Awards

- 2009 Praxis Unico - Environmental Impact Award for Microwave Processing of Vermiculite

- 2011 Institution of Chemical Engineers (IChemE) - The Energy Award 2011 for Microwave Processing of Vermiculite (in conjunction with e2v technologies plc)

- 2011 British Engineering Excellence Award - Manufacturing and Process Innovation (for Microwave processing - in conjunction with e2v technologies plc)

- 2011 Manufacturing and Process Innovation Award, The Engineer Technology and Innovation Awards, 2011 (for Microwave processing of vermiculite - in conjunction with e2v technologies plc)

- 2011 Royal Society of Chemistry - Beilby Medal and Prize "for work of exceptional practical significance in chemical engineering, applied materials science, energy efficiency or a related field." Sponsored by Institution of Materials, Minerals and Mining, Royal Society of Chemistry and $\mathrm{SCl}$ (individual) 
Appendix 6: Research Sponsors who have supported Research Activities

1. Kumba Resources

2. Engineering and Physical Sciences Research Council, UK

3. Department for Trade and Industry, UK

4. Innovate UK

5. Shell

6. BP Chemicals

7. BP Exploration

8. Amerada Hess

9. British Gas

10. Rio Tinto

11. Anglo American

12. Placer Dome

13. BHP Billiton

14. Western Mining Ltd

15. E.ON

16. National Grid

17. British Coal Utilisation Research Association

18. AMIRA International

19. FP6 and FP7, European Commission

20. Teledyne - e2v

21. Department for Environment, Food and Rural Affairs

22. Johnson Matthey

23. Akzo Nobel

24. Outotec

25. Tomra Ore Sorting

26. Lachesis Venture Capital Fund 